
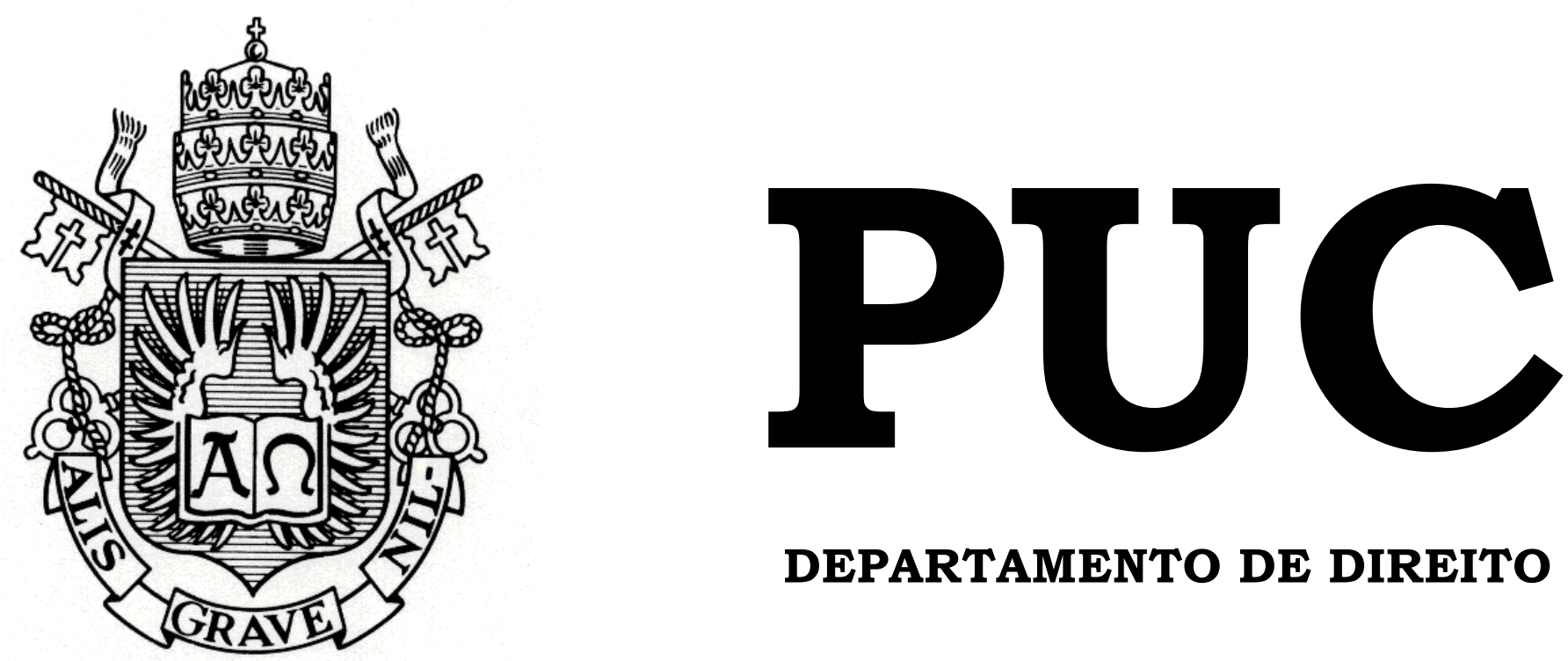

DEPARTAMENTO DE DIREITO

\title{
CONTROLE FRACO DE CONSTITUCIONALIDADE: 0 CASO DO REINO UNIDO
}

por

CLARA HANSON ANDRADE

ORIENTADOR: Prof. José Guilherme Berman 2018.2

PONTIFÍCIA UNIVERSIDADE CATÓLICA DO RIO DE JANEIRO RUA MARQUÊS DE SÃO VICENTE, 225 - CEP 22453-900 RIO DE JANEIRO - BRASIL 


\title{
CONTROLE FRACO DE CONSTITUCIONALIDADE: O CASO DO REINO UNIDO
}

\author{
por \\ CLARA HANSON ANDRADE
}

Monografia

apresentada

ao

Departamento de Direito da Pontifícia Universidade Católica do Rio de Janeiro (PUC-Rio) para a obtenção do Título de Bacharel em Direito.

Orientador: Prof. José Guilherme Berman 


\section{Agradecimentos}

Aos meus pais, por serem os meus maiores protetores e os meus melhores amigos, pelo apoio, parceria e amor incondicionais. Não há nenhum dia que eu não agradeça por ser filha de vocês.

In memoriam do meu irmão, Alexandre, responsável por grandes aprendizados que tive durante a minha vida, e da minha avó, Margareth, que será sempre a minha maior inspiração como profissional e como mulher.

À minha irmãzinha Luisa, que sempre me ajuda a ver o lado mais leve da vida, mesmo sem perceber.

Ao meu avô, Carlos, e ao meu tio, Dennis, pelo enorme apoio na fase final da monografia e em tantos outros momentos.

Às minhas melhores amigas do Santo Inácio e da vida, Ana Carolina, Ana Thais, Francine, Isabela, Maria Clara e Mariana, que, mesmo tendo seguido caminhos completamente diferentes do meu e nem sempre podendo estar por perto, fazem o possível para estarem presentes e continuam tendo um papel enorme na minha vida - e espero que sempre continuem tendo.

Às minhas queridas amigas da PUC, Alice, Brenda, Camila, Fernanda, Julia, Naomi e Vivian, por esses 5 intensos e maravilhosos anos compartilhados - a PUC é o que é para mim por causa de vocês.

A todos do Barbosa Müssnich Aragão, em especial: Rafael Castilho, Caio Sarti, Matheus Barcelos, Maria Eduarda Moog e Luisa Filgueiras, os maiores responsáveis pela minha formação profissional. É um orgulho imenso poder dizer que vocês foram os meus mentores. Aos meus amigos de baia, o meu mais sincero agradecimento por todos os momentos e risadas compartilhados - o BMA não seria o mesmo sem vocês.

Ao Prof. José Guilherme Berman, pela orientação e por ter compartilhado comigo o seu extenso conhecimento sobre o objeto desta monografia. 


\section{Resumo}

Esta monografia tem por objeto a análise do Direito Constitucional britânico, notadamente o modelo de controle de constitucionalidade adotado pelo Reino Unido - chamado por alguns autores de controle "fraco" de constitucionalidade ou weak-form judicial review -, criado pelo Human Rights Act em 1998, ato normativo responsável por incorporar ao direito britânico a Convenção Europeia de Direitos Humanos de 1950. Discorre-se, inicialmente, sobre os marcos históricos da Jurisdição Constitucional no mundo, em especial os modelos criados pelos Estados Unidos e pela Áustria, além de analisar-se brevemente o caso brasileiro. Depois, passa-se à análise do Direito Constitucional britânico, examinando-se a sua evolução e seus princípios fundamentais. Por fim, é exposto como se deu a implementação do modelo fraco de constitucionalidade no Reino Unido, ponderando-se os seus efeitos e chegando-se à conclusão que foi, de forma geral, bem-sucedido até o momento.

\section{PALAVRAS-CHAVE}

Direito Constitucional - Jurisdição Constitucional - Direito Comparado Controle Fraco de Constitucionalidade - Reino Unido 


\section{Sumário}

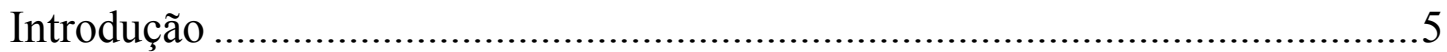

Capítulo 1 - $\mathrm{O}$ controle jurisdicional de constitucionalidade na História ...........7

1.1 Estados Unidos: o primeiro precedente e o surgimento do modelo

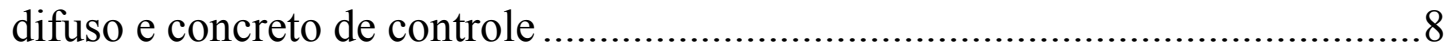

1.2 Áustria: o berço do modelo abstrato e concentrado de controle................11

$1.3 \mathrm{O}$ caso brasileiro: o controle misto de constitucionalidade ........................13

Capítulo 2 - O Direito Constitucional britânico ................................................18

$2.1 \mathrm{O}$ constitucionalismo político e a supremacia parlamentar .........................18

2.2 Princípios fundamentais da Constituição britânica.......................................23

2.3 O novo modelo de constitucionalismo da Commonwealth ..........................28

Capítulo 3 - O controle fraco de constitucionalidade no Reino Unido .............34

3.1 O Human Rights Act de 1998....................................................................

$3.2 \mathrm{O}$ caso dos prisioneiros de Belmarsh .......................................................40

3.3 Efetividade do controle fraco de constitucionalidade: a experiência britânica.

Conclusão.

Bibliografia .53 


\section{Introdução}

As Constituições escritas ganharam um importante papel no contexto pós $2^{\mathrm{a}}$ Guerra Mundial, visto que são uma forma de garantia dos direitos fundamentais dos cidadãos, tão brutalmente violados durantes as duas guerras que se antecederam.

Nesse contexto, o controle jurisdicional de constitucionalidade - um mecanismo criado para garantir a supremacia das normas constitucionais, conferindo ao Judiciário a autoridade para declarar normas do ordenamento jurídico incompatíveis com as normas constitucionais, deixando de aplicá-las ao caso concreto e/ou anulando-as - também passou a ser amplamente adotado no mundo como mais uma forma de garantia desses direitos.

Historicamente, o Reino Unido, que nunca adotou um modelo de Constituição escrita e sempre teve como princípio basilar a supremacia do Parlamento, resistiu em adotar essa espécie de controle, de forma a não ameaçar um princípio tão fundamental do seu ordenamento jurídico.

No entanto, o seu ingresso na Comunidade Europeia - que evoluiu posteriormente para a União Europeia - serviu como incentivo à implementação de alguma forma de jurisdição constitucional no país, uma vez que a aplicação das leis comunitárias acabou por gerar diversas condenações do Reino Unido nas Cortes Europeias, notadamente no que diz respeito à Convenção Europeia de Direitos Humanos.

Surgiu, assim, no final do século XX, o instituto do controle "fraco" de constitucionalidade no Reino Unido, sistema criado pelo Human Rights Act de 1998, através da concepção do instituto da declaração de incompatibilidade. O

Human Rights Act foi responsável por incorporar à legislação britânica a Convenção Europeia de Direitos Humanos de 1950, consagradora de diversas garantias, liberdades e direitos do indivíduo. 
O primeiro capítulo deste trabalho apresenta uma breve exposição sobre a evolução da jurisdição constitucional em âmbito mundial, tomando como base especialmente o caso americano e austríaco, os quais serviram de modelo para a maior parte dos demais países, além de uma curta análise sobre o caso brasileiro, no qual se optou por conjugar os modelos americano e austríaco.

O segundo capítulo explora o Direito Constitucional britânico, analisando os motivos do papel central da supremacia parlamentar neste ordenamento jurídico, passando pelos institutos jurídicos que compõem a Constituição britânica, e, por fim, fazendo uma breve exposição sobre o "novo modelo de constitucionalismo" da Commonwealth, suscitado por Stephen Gardbaum ${ }^{1}$.

O terceiro e último capítulo examina o modelo de controle de constitucionalidade adotado pelo Reino Unido, instituído pelo Human Rights Act 1998, bem como a sua efetividade, usando-se como exemplo um dos casos mais célebres do Direito Constitucional inglês, o dos prisioneiros de Belmarsh.

Por fim, o trabalho é concluído ponderando-se se o sistema de controle jurisdicional de constitucionalidade adotado por aquele país foi ou não bemsucedido, levando em conta as respostas oferecidas pelo Parlamento britânico às declarações de incompatibilidade emitidas pelo Judiciário.

\footnotetext{
${ }^{1}$ Cf. GARDBAUM, Stephen. The New Commonwealth Model of Constitutionalism. American Journal of Comparative Law, v. 49, 2001. p. 707-760.
} 


\section{Capítulo 1 - 0 controle jurisdicional de constitucionalidade na História}

As Constituições modernas possuem um importante papel de limitação dos poderes do Estado e proteção de determinadas liberdades e direitos tidos como fundamentais, assegurando-lhes um tratamento prioritário ${ }^{2}$.

Nesse sentido, o controle de constitucionalidade se mostra como um instituto capaz de proteger estes direitos fundamentais constitucionalmente previstos das maiorias transitórias que ocupam o Legislativo e o Executivo ${ }^{3}$. Dessa forma, o seu papel deve ser entendido como o exercício de uma função contramajoritária, de proteção da vontade do povo, uma vez que esta estaria "cristalizada nos princípios insculpidos na Constituição"4 e o Judiciário estaria defendendo as normas nela previstas.

Vale observar que a tendência de adoção de Constituições com um forte papel de garantia de direitos fundamentais pelo mundo se deu, sobretudo, no contexto pós $2^{\text {a }}$ Guerra Mundial ${ }^{5}$, durante a qual, como se sabe, houve uma violação brutal desses direitos pelos governos autocráticos. Assim, essa tendência se deu em razão da intenção de se evitar uma nova ascensão desses governos e a garantir ao povo que tudo que ocorreu durante as guerras que se antecederam não viria a acontecer novamente.

Nem mesmo essa tendência mundial no contexto pós-guerra fez com que o Reino Unido imediatamente deixasse de lado o chamado constitucionalismo político, uma vez que continuou optando por não ter uma constituição escrita e instrumentalizada em um único documento dotado de rigidez ${ }^{6}$. Por motivos que

\footnotetext{
${ }^{2}$ BINENBOJM, Gustavo. A nova jurisdição constitucional: Legitimidade democrática e instrumentos de realização. $4^{\mathrm{a}}$ ed. revista, ampliada e atualizada. Rio de Janeiro: Renovar, 2014. p. 80.

${ }^{3}$ Ibid.

${ }^{4}$ Ibid. p. 81.

${ }^{5}$ BERMAN, José Guilherme. Controle fraco de constitucionalidade: sistema jurídico contemporâneo e direito constitucional comparado. Curitiba: Juruá, 2014. p. 21.

${ }^{6}$ Ibid. p. 169.
} 
serão expostos mais adiante, apenas ao final do século XX é que este país decidiu adotar uma forma de controle de constitucionalidade (mesmo que mais branda), de modo a conferir ao Judiciário uma função contramajoritária.

Visando elucidar melhor o instituto do controle jurisdicional de constitucionalidade, faremos aqui, incialmente, uma breve exposição sobre o surgimento das suas duas formas mais conhecidas de controle, quais sejam: o controle difuso e concreto e o controle concentrado e abstrato, que foram concebidos, respectivamente, pelos Estados Unidos e pela Áustria. Além disso, será feita, ainda, uma curta análise sobre a forma adotada pelo direito brasileiro, chamada de controle misto de constitucionalidade, uma vez que conjuga os dois modelos supramencionados.

\subsection{Estados Unidos: o primeiro precedente e o surgimento do modelo difuso e concreto de controle}

Os Estados Unidos, além de possuir a primeira Constituição escrita do mundo ${ }^{7}$, promulgada em 1787 e em vigor até hoje, foi o primeiro país a adotar na prática o controle de constitucionalidade ${ }^{8}$. Na verdade, o instituto não foi criado pela Constituição americana, mas sim através de uma construção jurisprudencial, inaugurada pelo emblemático caso Marbury v. Madison, julgado em 1803.

Apesar de a possibilidade de se existir um controle jurisdicional de leis já haver sido debatida previamente pela doutrina - da qual podemos citar o inglês

\footnotetext{
${ }^{7}$ BINENBOJM, Gustavo. A nova jurisdição constitucional: Legitimidade democrática e instrumentos de realização. $4^{\text {a }}$ ed. revista, ampliada e atualizada. Rio de Janeiro: Renovar, 2014. p. 25.

${ }^{8}$ BARROSO, Luís Roberto. O controle de constitucionalidade no direito brasileiro: exposição sistemática da doutrina e análise crítica da jurisprudência. $4^{a}$ ed. rev. e atual.. São Paulo: Saraiva, 2009. p. 2.
} 
Sir Edward Coke 9 e o federalista americano Alexander Hamilton ${ }^{10}-$, Marbury v. Madison foi o primeiro caso em que uma Corte efetivamente deixou de aplicar uma lei por considerá-la inconstitucional.

Neste caso, a questão de mérito tinha como pano de fundo uma tensão política decorrente da derrota na eleição presidencial do federalista John Adams (candidato à reeleição) para o republicano Thomas Jefferson. Visando garantir uma maior influência dos federalistas no Judiciário, já que haviam perdido a sua representatividade no Executivo e no Legislativo, John Adams e os federalistas, dentre outras medidas, resolveram nomear diversos juízes de paz nas últimas semanas do mandato de Adams ${ }^{11}$.

No entanto, como não houve tempo hábil para entregar todos os títulos de nomeação antes do fim do seu mandato - para que os juízes de paz pudessem efetivamente tomar posse -, alguns títulos deveriam ser entregues já no novo governo republicano. Thomas Jefferson, contudo, visando sabotar a medida tomada pelos federalistas, orientou que seu Secretário de Estado, James Madison, não entregasse os títulos restantes, ordem prontamente cumprida ${ }^{12}$.

Inconformado com a decisão do novo governo, William Marbury, um dos juízes de paz nomeados que não conseguiu tomar posse, decidiu impetrar um writ of mandamus perante a Suprema Corte americana para ter o seu direito assegurado.

\footnotetext{
${ }^{9}$ O jurista Mauro Cappelletti expõe que a doutrina do inglês Sir Edward Coke consistia na ideia de supremacia da common law sobre a autoridade do Parlamento, que deveria ter seus atos declarados nulos pelo Judiciário caso contrariassem a commom law. Vale observar que tal doutrina cedeu espaço à ideia de supremacia parlamentar durante a Revolução Gloriosa, como se verá no próximo capítulo. Neste sentido, cf. CAPPELLETTI, Mauro. O controle judicial de constitucionalidade das leis no direito comparado. Tradução de Aroldo Plínio Gonçalves. $2^{\mathrm{a}}$ ed., reimpressão. Porto Alegre: Fabris, 1984. p. 58-60.

${ }^{10}$ Conforme esclarece Binenbojm, Alexander Hamilton expôs em seu artigo no The Federalist que, como a Constituição é a lei fundamental, seria papel do Judiciário declarar a nulidade das leis infraconstitucionais que fossem contrárias a ela (BINENBOJM, Gustavo. A nova jurisdição constitucional: Legitimidade democrática e instrumentos de realização. $4^{\mathrm{a}}$ ed. revista, ampliada e atualizada. Rio de Janeiro: Renovar, 2014. p. 27).

${ }^{11}$ BARROSO, Luís Roberto. O controle de constitucionalidade no direito brasileiro: exposição sistemática da doutrina e análise crítica da jurisprudência. $4^{a}$ ed. rev. e atual.. São Paulo: Saraiva, 2009. p. 3-4.

${ }^{12}$ Ibid.
} 
Embora o presidente da Suprema Corte americana, John Marshall ${ }^{13}$, tenha proclamado expressamente em seu voto a existência do direito de Marbury de ser nomeado no caso em tela, o juiz deixou de conceder o writ porque considerou que a lei que conferia a competência originária da Suprema Corte para julgar o remédio utilizado por Marbury violava a Constituição americana, que previa taxativamente as suas competências, não cabendo ao legislador ordinário ampliar as hipóteses de competência originária da Suprema Corte ${ }^{14}$.

Assim, em que pese a concordância de Marshall quanto à existência do direito de Marbury, o writ of mandamus foi denegado em razão de uma questão preliminar processual, qual seja, a inconstitucionalidade da lei que estabeleceu a competência originária da Suprema Corte para julgar tal remédio.

Frise-se que o fundamento constitucional de Marshall para exercer o controle de constitucionalidade da norma foi puramente o conceito de supremacia da Constituição, previsto no art. $6^{\circ}$ da Constituição americana ${ }^{15}$, que dispõe que as normas contidas nesta são, em seus exatos termos, "the supreme Law of the Land", devendo as leis infraconstitucionais serem elaboradas em cumprimento a elas.

Assim, partindo-se da premissa da superioridade da Constituição em relação às demais normas legais, chegar-se-ia à conclusão de qualquer lei contrária a ela é nula e, portanto, não pode ser aplicada ${ }^{16}$. E, seguindo esta lógica, como competiria ao Judiciário decidir qual seria a norma aplicável em casos de conflito, também caberia a este deixar de aplicar a norma que considerar inconstitucional.

\footnotetext{
${ }^{13}$ Cumpre mencionar que John Marshall, inclusive, foi designado para o cargo de presidente da Suprema Corte americana justamente pelo presidente John Adams, em mais uma de suas medidas tomadas ao final de seu mandato para garantir a influencia dos federalistas no Judiciário - fato gerador de ainda mais tensão política antes da decisão.

${ }^{14}$ BINENBOJM, Gustavo. A nova jurisdição constitucional: Legitimidade democrática e instrumentos de realização. $4^{\mathrm{a}}$ ed. revista, ampliada e atualizada. Rio de Janeiro: Renovar, 2014. p. 31.

${ }^{15}$ BERMAN, José Guilherme. Controle fraco de constitucionalidade: sistema jurídico contemporâneo e direito constitucional comparado. Curitiba: Juruá, 2014. p. 48.

${ }^{16}$ Ibid. p. 49.
} 
Dessa forma, vê-se que o sistema de controle de constitucionalidade americano não é fruto de expressa previsão legal, e sim de uma construção jurisprudencial, que teve como marco o caso supramencionado. Nesse sentido, expõe Gardbaum:

“É claro que a própria Constituição não contém uma concessão clara do poder de revisão judicial aos tribunais, mas foi inferida pelo Presidente da Suprema Corte Marshall (e outros) pelo status da Constituição como lei suprema, em si (em relação à legislação federal), uma inferência estrutural a partir de sua natureza escrita."17

Assim, o que se observa é que o controle de constitucionalidade, como delineado pelos americanos, foi concebido mais de 15 anos após a promulgação da Constituição americana, através de uma decisão da Suprema Corte, que acabou se tornando a decisão que "inaugurou o controle de constitucionalidade no constitucionalismo moderno" ${ }^{\prime 18}$.

Digno de nota o fato de que, até os dias de hoje, o controle de constitucionalidade nos Estados Unidos só é feito na forma concreta e difusa, ou seja, é realizado apenas no âmbito de casos concretos, podendo ser exercido por qualquer membro do Poder Judiciário ${ }^{19}$ - diversamente do modelo austríaco, que será analisado a seguir.

\section{2 Áustria: o berço do modelo abstrato e concentrado de controle}

\footnotetext{
${ }^{17}$ GARDBAUM, Stephen. The New Commonwealth Model of Constitutionalism. American Journal of Comparative Law, v. 49, 2001. p. 712, tradução livre. No original: "Of course, the Constitution itself contains no clear grant of the power of judicial review to the courts, but was inferred by Chief Justice Marshall (and others) from the status of the Constitution as supreme law, itself (with respect to federal legislation) a structural inference from its written nature."

${ }_{18}$ BARROSO, Luís Roberto. O controle de constitucionalidade no direito brasileiro: exposição sistemática da doutrina e análise crítica da jurisprudência. $4^{a}$ ed. rev. e atual.. São Paulo: Saraiva, 2009. p. 10 .

${ }^{19}$ BERMAN, José Guilherme. Controle fraco de constitucionalidade: sistema jurídico contemporâneo e direito constitucional comparado. Curitiba: Juruá, 2014. p. 51-52.
} 
O modelo de controle de constitucionalidade abstrato e concentrado foi originalmente concebido pelo célebre jurista austríaco Hans Kelsen, tendo sido adotado na prática pela primeira vez pela Constituição da Áustria de $1920^{20}$.

Conforme sintetizado por Binenbojm, a visão de Kelsen baseia-se na ideia de que o controle de constitucionalidade consistiria em um mero procedimento específico constitucionalmente previsto para a revogação de uma lei, um procedimento alternativo ao tradicional - que seria a edição de nova lei que revogue a anterior ${ }^{21}$.

Assim, na concepção kelseniana, uma lei inconstitucional é válida até que ela seja anulada pelo procedimento próprio e pelo órgão competente, possuindo a declaração de inconstitucionalidade, para tanto, efeitos ex nunc e erga omnes, ou seja, a partir da sua declaração (não retroagindo à data da edição da norma) e oponíveis a todos $^{22}$. De tal modo, não poderia o Judiciário deixar de aplicar uma lei até que ela fosse anulada - tarefa que caberia, para Kelsen, a um tribunal constitucional criado para este fim, e não ao Judiciário de forma geral ${ }^{23}$.

Com fundamento na concepção de Kelsen, a Constituição austríaca de 1920 conferiu somente à Corte Constitucional a competência para julgar questões de inconstitucionalidade - o que caracteriza o modelo de controle concentrado, uma vez que seu exercício é "concentrado" em um único órgão -, além de subordinar o controle ao ajuizamento de uma ação específica, desvinculada de casos concretos - característica que identifica o controle abstrato -, cuja legitimidade para o ajuizamento caberia a apenas alguns órgãos políticos nela previstos ${ }^{24}$.

Neste sentido, Cappelletti sintetiza o modelo austríaco de controle de constitucionalidade:

\footnotetext{
${ }^{20}$ BINENBOJM, Gustavo. A nova jurisdição constitucional: Legitimidade democrática e instrumentos de realização. $4^{\mathrm{a}}$ ed. revista, ampliada e atualizada. Rio de Janeiro: Renovar, 2014. p. 35-37.

${ }^{21}$ Ibid. p. 36-37.

${ }^{22}$ Ibid. p. 36.

23 BARROSO, Luís Roberto. O controle de constitucionalidade no direito brasileiro: exposição sistemática da doutrina e análise crítica da jurisprudência. $4^{a}$ ed. rev. e atual.. São Paulo: Saraiva, 2009. p. 19.

${ }^{24}$ BINENBOJM, Gustavo. Op.cit. p. 37-38.
} 
"Em posição diametralmente oposta ao sistema americano, colocou-se o sistema austríaco de controle de constitucionalidade das leis, especialmente na formulação originária (em seguida parcialmente mudada, como veremos) que este sistema teve na Bundesverfassung austríaca, de $1^{\circ}$ de outubro de 1920 . De fato, esta Constituição não só criou uma especial Corte Constitucional - o Verfassungsgerichtshof - na qual "concentrou" a competência exclusiva para decidir as questões de constitucionalidade, mas, além disso, a Constituição austríaca confiou a esta corte um poder de controle que, para ser exercido, necessitava de um pedido especial ("Antrag"), isto é, do exercício de uma ação especial por parte de alguns órgãos políticos. Desta sorte, o controle de legitimidade das leis vinha a ser, na Áustria, diversamente dos Estados Unidos da América, inteiramente desvinculado dos casos concretos, vale dizer, dos processos comuns (civis, penais, administrativos); ele, por conseguinte, em vez de poder ser exercido, como na América, tão-só "em via incidental", isto é, (como, também, com certa impropriedade se diz) "em via de exceção", devia ser exercido, na Áustria, sempre "em via principal", ou seja, "em via de ação", mediante um adequado e autônomo processo ad hoc perante a Corte Constitucional.",25

Observa-se, aqui, que na formulação original da Constituição austríaca não era sequer prevista a possibilidade de juízes declararem incidentalmente a inconstitucionalidade de uma lei, deixando de aplicá-la em um caso concreto, nos exatos termos idealizados por Kelsen. No entanto, a reforma constitucional de 1929 incluiu na Constituição da Áustria a possibilidade de exercício de um controle dentro de casos concretos, porém ainda a ser exercido apenas de forma concentrada, pela Corte Constitucional ${ }^{26}$.

O modelo austríaco passou a ser mais amplamente adotado na Europa continental no contexto pós $2^{\mathrm{a}}$ Guerra Mundial, notadamente pelos seguintes países: Alemanha (1949), Itália (1956), Chipre (1960), Turquia (1961) e na extinta Iugoslávia $(1963)^{27}$, tendo sido adotado pelo Brasil em 1965, como se verá a seguir.

\subsection{0 caso brasileiro: o controle misto de constitucionalidade}

\footnotetext{
${ }^{25}$ CAPPELLETTI, Mauro. O controle judicial de constitucionalidade das leis no direito comparado. Tradução de Aroldo Plínio Gonçalves. $2^{\mathrm{a}}$ ed., reimpressão. Porto Alegre: Fabris, 1984. p. 104-105.

${ }^{26}$ BINENBOJM, Gustavo. A nova jurisdição constitucional: Legitimidade democrática e instrumentos de realização. $4^{a}$ ed. revista, ampliada e atualizada. Rio de Janeiro: Renovar, 2014. p. 38.

${ }^{27}$ Ibid. p. 39.
} 
Conforme previamente mencionado, o sistema de controle de constitucionalidade adotado pelo Brasil pode ser enquadrado em uma categoria mista, pois conjuga os dois modelos acima descritos - o americano e o austríaco. Inicialmente foi instituído, pela primeira Constituição republicana (de 1891) e com inspiração na experiência americana, o modelo de controle concreto e difuso, segundo o qual a inconstitucionalidade poderia ser suscitada pelas partes de um processo em qualquer instância ${ }^{28}$.

Esse sistema evoluiu nas Constituições seguintes, acrescentando-se novas regras e limitações ${ }^{29}$, até que, na Emenda Constitucional $n^{\circ}$ 16, de 1965, acrescentada à Constituição de 1946, consagrou-se o modelo abstrato e concentrado de controle. Nesta emenda, foi criada a figura da representação de inconstitucionalidade, uma ação genérica de inconstitucionalidade que poderia ser encaminhada somente pelo Procurador-Geral da República ao Supremo Tribunal Federal ${ }^{30}$.

Finalmente, a Constituição de 1988 (“CRFB"), vigente até a presente data e consagrada como a "Constituição cidadã", uma vez que ampliou significativamente os mecanismos de proteção aos direitos fundamentais nela previstos $^{31}$, ampliou também o sistema de controle de constitucionalidade, criando-se, por exemplo, a ação direta de inconstitucionalidade (“ADIn”),

${ }^{28}$ MENDES, Gilmar Ferreira. Curso de direito constitucional. $11^{\mathrm{a}}$ ed.. São Paulo: Saraiva, 2016. p. 1.109-1.110.

${ }^{29}$ Dentre essas novas regras, a mais relevante delas foi criada pela Constituição brasileira de 1934, que concebeu o instituto da representação interventiva, que exigia que a Corte Suprema declarasse previamente a constitucionalidade de lei que decretasse a intervenção federal com base em violação a princípios constitucionais sensíveis, por provocação do Procurador-Geral da República. Essa foi a primeira hipótese específica de controle concentrado introduzida ao direito brasileiro, mas que ainda se tratava de uma forma de controle concreto. Observa-se que tal ação também é prevista na Constituição brasileira atualmente vigente (BARROSO, Luís Roberto. O controle de constitucionalidade no direito brasileiro: exposição sistemática da doutrina e análise crítica da jurisprudência. $4^{\mathrm{a}}$ ed. rev. e atual.. São Paulo: Saraiva, 2009. p. 63).

${ }^{30}$ BARROSO, Luís Roberto. Op.cit, 2009. p. 63-64.

${ }^{31}$ Nesse sentido, a CRFB criou, por exemplo, dois novos remédios constitucionais, quais sejam, o habeas data, previsto no inciso LXXII do seu art. $5^{\circ}$, que visa a garantir o direito de autodeterminação do indivíduo sobre as informações; e o mandado de injunção, previsto no inciso LXXI do mesmo artigo, a ser utilizado contra omissões de órgãos legislativos que tenham impedido o exercício de um direito constitucionalmente assegurado (MENDES, Gilmar Ferreira. Curso de direito constitucional. $11^{\mathrm{a}}$ ed.. São Paulo: Saraiva, 2016. p. 1.127). 
possibilitando que o Supremo Tribunal Federal ("STF") declarasse lei ou ato normativo federal ou estadual inconstitucional, além de ampliar-se significativamente o rol de legitimados à interposição das ações diretas (CRFB, art. 102, I, $a$ c/c art. 103) ${ }^{32}$.

Além da ADIn, foi também criada a ação declaratória de constitucionalidade (“ADC”), através da Emenda Constitucional no 3 de 1993, que permitiu que os mesmos legitimados à interposição da $\mathrm{ADIn}^{33}$ requeressem a declaração de constitucionalidade de determinada lei, quando houvesse "controvérsia judicial relevante" acerca da sua aplicação (conforme dispõe o art. 14, inciso III, da Lei no 9.868/1999).

Criou-se, ainda, mais dois tipos de ações diretas: a ação direta de inconstitucionalidade por omissão ("ADIn por omissão") e a arguição de descumprimento de preceito fundamental (“ADPF”). A ADIn por omissão permite que o Supremo Tribunal Federal declare uma omissão do dever constitucional de legislar ou de adotar determinada providência administrativa, dando-se ciência ao órgão competente para que adote as providências necessárias ${ }^{34}$.

A ADPF, por outro lado, prevista no art. $103, \S 1^{\circ}$, da CRFB, expandiu de forma significativa o sistema de controle de constitucionalidade brasileiro, pois passou a ocupar um espaço residual expressivo, que antes cabia ao controle difuso, possibilitando a análise pelo STF de matérias não suscetíveis de exame em sede de controle concentrado, como, por exemplo, as leis municipais ${ }^{35}$. Tamanha foi amplitude conferida pelo constituinte à ADPF, que somente com a

\footnotetext{
${ }^{32}$ MENDES, Gilmar Ferreira. Curso de direito constitucional. $11^{\text {a }}$ ed.. São Paulo: Saraiva, 2016. p. 1.126-1.128.

${ }^{33}$ Observa-se aqui que a ADC só passou a ter os mesmos legitimados da ADIn a partir da Emenda Constitucional $n^{\circ}$ 45/2004 (MENDES, Gilmar Ferreira. Curso de direito constitucional. $11^{\text {a }}$ ed.. São Paulo: Saraiva, 2016. p. 1.131).

${ }^{34}$ Conforme art. 12-B, inciso I c/c art. 12-H, da Lei no 9.868/1999.

${ }^{35}$ MENDES, Gilmar Ferreira. Op.cit. p. 1.131.
} 
edição da lei que a regulamentou (Lei n ${ }^{\circ}$ 9.882/1999), mais de 10 anos após sua criação, é que foi possível a sua utilização pelos legitimados ${ }^{36}$.

Assim, nota-se que há uma tendência no Brasil, inaugurada pela Constituição de 1988, de valorização do modelo austríaco de controle de constitucionalidade, seja pela ampliação do rol de legitimados para ajuizamento das chamadas "ações diretas", seja pela criação de diversos mecanismos de controle abstrato - no qual se alega a violação a norma constitucional por uma lei em abstrato -, e não no âmbito de um caso concreto, passando o modelo americano a ocupar um papel mais residual ${ }^{37}$.

Deste modo, permitindo-se que a maior parte das controvérsias acerca da constitucionalidade fossem resolvidas pelo Supremo Tribunal Federal, tornouse cada vez mais reduzida a importância do controle de constitucionalidade incidental $^{38}$.

Apesar de todas as diferenças apontadas, os sistemas previamente mencionados - americano, austríaco e o brasileiro - possuem uma característica em comum: tratam-se de modelos de controle "forte" de constitucionalidade, no qual a lei declarada inconstitucional deixa de ser aplicada pelo Judiciário e é invalidada.

Como se verá adiante, o modelo britânico de controle, apesar de adotar características dos dois modelos acima expostos - uma vez que é um controle feito de forma concentrada, como o austríaco, pois concentrado em algumas das cortes mais altas do Judiciário britânico, mas concreto, como o americano, pois sempre realizado no âmbito da análise de um caso concreto -, caracteriza-se

\footnotetext{
${ }^{36}$ Neste ponto, observa-se que a primeira ADPF foi ajuizada apenas em 27 jan. 2000, mais de 10 anos após a sua criação, mas poucos meses após a sua regulamentação pela Lei ${ }^{\circ}$ 9.882/1999. Nesse sentido, cf. ADPF $n^{\circ} 1 \mathrm{em} \mathrm{http://portal.stf.jus.br/processos/detalhe.asp?incidente=1804019.} \mathrm{Acesso} \mathrm{em} 15$ nov. 2018.

37 BARROSO, Luís Roberto. O controle de constitucionalidade no direito brasileiro: exposição sistemática da doutrina e análise crítica da jurisprudência. $4^{a}$ ed. rev. e atual.. São Paulo: Saraiva, 2009. p. 67.

${ }^{38}$ MENDES, Gilmar Ferreira. Curso de direito constitucional. $11^{\mathrm{a}}$ ed.. São Paulo: Saraiva, 2016. p. 1.128-1.129.
} 
como um controle "fraco" de constitucionalidade, no qual o Judiciário não pode deixar de aplicar a lei, mas apenas apontar a inconstitucionalidade ao órgão que a editou. 


\section{Capítulo 2 - O Direito Constitucional britânico}

\subsection{0 constitucionalismo político e a supremacia parlamentar}

Para melhor se compreender o motivo de o Reino Unido ter resistido por tanto tempo a adotar um sistema jurisdicional de controle de constitucionalidade e o fato de, ao adotá-lo, fazê-lo de forma branda (ou "fraca"), é necessário entender, primeiramente, o funcionamento do Direito Constitucional britânico.

Stephen Gardbaum, ao definir a Constituição britânica, esclarece que:

“A constituição britânica não é um documento único ou um grupo de documentos, mas
um agregado de leis (estatutárias e da common law), regras, princípios, convenções e
práticas que coletivamente definem a composição, funções, e inter-relações das
instituições governamentais, e delineiam os direitos e deveres dos governados.",

De tal modo, o Reino Unido se apresenta como um dos pouquíssimos países que não adotam uma Constituição sistematizada em um único documento - acompanhado por Israel e pela Nova Zelândia ${ }^{40}$. Como se verá a seguir, a Constituição inglesa é composta, na verdade, por princípios fundamentais, e não por regras pré-definidas. Do mesmo modo, pode-se dizer que o Reino Unido possui um sistema constitucional flexível, no qual as normas ditas constitucionais possuem a mesma forma de alteração de qualquer outra lei ordinária do Reino Unido.

Nesse sentido, o Direito Constitucional britânico, para diversos autores ${ }^{41}$, poderia ser classificado como um constitucionalismo político, no qual os fatores

\footnotetext{
${ }^{39}$ GARDBAUM, Stephen. The New Commonwealth Model of Constitutionalism. American Journal of Comparative Law, v. 49, 2001. p. 711, tradução livre. No original: "The British constitution is not a single document or group of documents, but is the aggregate set of laws (statutory and common law), rules, principles, conventions, and practices that collectively define the composition, functions, and interrelationships of the institutions of government, and delineate the rights and duties of the governed."

${ }^{40}$ BARROSO, Luís Roberto. Curso de direito constitucional contemporâneo: os conceitos fundamentais e a construção do novo modelo. $2^{\mathrm{a}}$ ed.. São Paulo: Saraiva, 2010. p. 81.

${ }^{41}$ Nesse sentido, cf. BERMAN, José Guilherme. Controle fraco de constitucionalidade: sistema jurídico contemporâneo e direito constitucional comparado. Curitiba: Juruá, 2014. p. 87-89.
} 
limitantes do poder do Estado não estão estabelecidos em leis dotadas de supremacia legal, cuja última palavra em relação à sua aplicação seja do Judiciário, mas sim contidos na História e na prática política do país, desenvolvida ao longo do tempo ${ }^{42}$. Ao não conferir tal poder ao Judiciário, se reconhece um papel bem mais amplo aos governantes, sendo a Constituição uma mera declaração política daqueles que detêm o poder em determinado momento.

Segundo Berman, isso ocorre porque, para os ingleses "o legislativo é justamente a fonte dos direitos que historicamente foram reconhecidos como obstáculos ao exercício do poder por parte do Executivo"43.

Observa-se que, em oposição a esse modelo, estaria o conceito de constitucionalismo jurídico, a forma mais comum de Direito Constitucional, segundo o qual a Constituição de um país é representada por um único documento, dotado de determinadas características que o diferenciariam das demais normas infraconstitucionais ${ }^{44}$ - tais como a rigidez e a supremacia -, e no qual se atribui ao Judiciário o papel de proteção e aplicação das normas constitucionais.

Conforme anteriormente mencionado, no caso do Reino Unido, esse caráter político da Constituição se deu, sobretudo, em razão do prestígio conferido ao princípio da soberania parlamentar. Para melhor compreender os motivos desse prestígio do Parlamento no direito britânico, será necessário voltar alguns séculos na História da Inglaterra ${ }^{45}$.

No início da História deste país, a titularidade do exercício do poder era exclusiva dos monarcas. Como se verá a seguir, esse poder foi sofrendo, aos poucos, limitações por diversas instituições, sobretudo pelo Parlamento. O

\footnotetext{
${ }^{42}$ BERMAN, José Guilherme. Controle fraco de constitucionalidade: sistema jurídico contemporâneo e direito constitucional comparado. Curitiba: Juruá, 2014. p. 87.

${ }^{43}$ Ibid. p. 88-89.

${ }^{44}$ Ibid. p. 42.

${ }^{45}$ Nesse sentido, cf. BERMAN, José Guilherme. Op.cit. p. 89-92; e BARROSO, Luís Roberto. Curso de direito constitucional contemporâneo: os conceitos fundamentais e a construção do novo modelo. $2^{\mathrm{a}}$ ed.. São Paulo: Saraiva, 2010. 453 p. 10-14.
} 
Parlamento britânico começou a ganhar forma no século XIII, quando a sua convocação e controle ainda eram exercidas pelo rei, sendo o Parlamento constituído, inicialmente, por representantes dos aristocratas, dos clérigos, da baixa aristocracia e da burguesia urbana, não havendo ainda uma plena representação popular.

Para explicar o fenômeno da evolução do papel do Parlamento na Inglaterra, o autor britânico Walter Bagehot divide a história constitucional inglesa em três períodos ${ }^{46}$.

$\mathrm{O}$ primeiro deles seria o período anterior à dinastia Tudor, em uma Inglaterra ainda feudal, no qual o Parlamento inglês começou a ganhar força e poder em decorrência da incerteza e descrença da população quanto ao titular da Coroa. Neste período, a maior força popular estava concentrada nas mãos da aristocracia, sobretudo da alta nobreza, a qual se constituía como um canal de comunicação entre a população e o rei ${ }^{47}$. Neste momento, o Parlamento ainda se caracterizava como um órgão meramente consultivo.

Não havia, naquele momento, um poder positivo do Parlamento de legislar, mas sim um papel negativo em relação às leis reais, qual seja, de impedir que o rei criasse leis que contrariassem os princípios mais básicos da common law e adotasse medidas extremamente impopulares. De tal modo, o rei só editava uma lei após consultar os seus parlamentares, já considerados na época como representantes do povo. Neste sentido, expõe Bagehot:

"Que o rei não poderia mudar o que eram, naquela época, os dados praticamente
sagrados da common law, sem checar se a sua nação estava de acordo ou não, era uma
parte essencial desse sistema "experimental". O rei deveria testar o sentimento popular
antes de praticar este ato excepcional e singular, já que naquela época julgava-se a
legislação nova, até mesmo os atos mais simples. O poder de legislar era seu afinal; ele

${ }^{46}$ BAGEHOT, Walter. Its History, and the Effects of That History - Conclusion. In: BAGEHOT, Walter. The English Constitution. $2^{\mathrm{a}} \quad$ ed.. 1873. p. 204-213. Disponível em $<$ https://socialsciences.mcmaster.ca/econ/ugcm/3113/bagehot/constitution.pdf $>$. Acesso em 15 nov. 2018.

${ }^{47}$ BERMAN, José Guilherme. Controle fraco de constitucionalidade: sistema jurídico contemporâneo e direito constitucional comparado. Curitiba: Juruá, 2014. p. 90. 
editava as leis depois de consultar seus Lordes e Comuns; sua palavra era sagrada e conferia a sacra solidez às normas, mas ele apenas ousava alterar a regra que regulava a vida comum de seu povo após consultá-los; ele não seria obedecido se não o tivesse feito, em uma época primitiva em que não se temia a guerra civil como nós tememos atualmente." 48

Assim, as leis promulgadas neste período possuíam um caráter mais declaratório do que propriamente constitutivo de novos direitos (como atualmente a legislação é comumente entendida). Consistiam as leis da época, portanto, em espécies de tratados entre diferentes ordens sociais, que apenas confirmavam direitos milenares decorrentes de convenções.

Neste contexto nasceu, por exemplo, a notória Magna Carta de 1215, na qual se positivou a necessidade de o monarca consultar o conselho real antes de criar novos impostos - tratando tal disposição, para Bagehot, de mero desdobramento da doutrina que já prevalecia no período pré-Tudor, qual seja, do dever do monarca de consultar seus conselheiros antes de praticar qualquer ato, papel consultivo já exercido pelo Parlamento antes da edição da Magna $\mathrm{Carta}^{49}$.

No entanto, as guerras civis que se sucederam acabaram por extinguir os conselhos reais existentes durante este período, uma vez que derrotaram parte da nobreza e aristocracia ${ }^{50}$. Inicia-se, então, o segundo período do Direito Constitucional britânico, marcado pela ascensão da Dinastia Tudor ao poder após o fim da Guerra das Rosas em 1485, e pelo breve período republicano britânico, liderado por Oliver Cromwell, entre 1649 e 1660.

\footnotetext{
${ }^{48}$ BAGEHOT, Walter. Its History, and the Effects of That History - Conclusion. In: BAGEHOT, Walter. The English Constitution. $2^{\mathrm{a}}$ ed.. 1873. p. 206, tradução livre. No original: "That the king could not change what was then the almost sacred datum of the common law, without seeing whether his nation liked it or not, was an essential part of the "tentative" system. The king had to feel his way in this exceptional, singular act, as those ages deemed original legislation, as well as in lesser acts. The legislation was his at last; he enacted after consulting his Lords and Commons; his was the sacred mouth which gave holy firmness to the enactment; but he only dared alter the rule regulating the common life of his people after consulting those people; he would not have been obeyed if he had not, by a rude age which did not fear civil war as we fear it now".

${ }^{49}$ BAGEHOT, Walter. Op.cit. p. 207.

${ }^{50}$ Ibid.
} 
Nesta época, ocorreu, em curta suma, um lento e progressivo desenvolvimento da supremacia parlamentar, que se deu, sobretudo, pelo crescimento da classe média inglesa e por influência do Protestantismo ${ }^{51}$.

Por fim, o terceiro e último período teve início precisamente em 1688, quando se iniciou a chamada Revolução Gloriosa, que teve por objetivo a destituição do rei católico James II, causador de enorme insatisfação de todas as classes sociais em relação à realeza, em razão da ameaça ao Protestantismo que este monarca representava.

Tamanha impopularidade do monarca acabou por culminar em uma inédita conciliação entre os defensores habituais da realeza e a sua tradicional oposição, que decidiram, em conjunto, restringir os poderes do rei, e estabelecer, definitivamente, a soberania parlamentar, através da Bill of Rights de 1689. Frise-se que, desde então, manteve-se intacto o respeito a tal princípio, alterando-se apenas o modo de exercício dessa soberania através dos anos ${ }^{52}$.

Como se observa, historicamente, a tendência foi que o povo inglês tivesse certa rejeição pelo Poder Executivo, quase sempre representado pela figura do monarca, tendo a conquista da sua liberdade sido marcada pela imposição de limites à monarquia pelo Parlamento. De tal modo, o Parlamento sempre foi entendido como o verdadeiro representante do povo, como a instituição que resistiu à tirania dos monarcas, o que justifica o seu papel central no Direito Constitucional britânico.

É de se notar que esse modo de pensar do povo inglês vai na direção oposta da maior parte dos povos do resto do mundo. Pode-se dizer que, além da História política inglesa narrada, a descrença dos cidadãos britânicos com o Executivo perdura, de certa forma, em decorrência do fato de que, além da figura do monarca - que hoje em dia ocupa um papel quase figurativo no Direito

\footnotetext{
${ }^{51}$ Ibid.

${ }^{52}$ Nesse sentido, BAGEHOT, Walter. Its History, and the Effects of That History - Conclusion. In: BAGEHOT, Walter. The English Constitution. $2^{\mathrm{a}}$ ed.. 1873. p. 209: "Though the rule of Parliament was definitely established in 1688, yet the mode of exercising that rule has since changed".
} 
britânico -, nem mesmo o Primeiro-Ministro britânico é escolhido diretamente pelo povo, uma vez que os cidadãos votam apenas nos seus representantes no Parlamento, sendo certo que o líder do partido político que alcançar a maioria dos votos do Parlamento é que será o Primeiro-Ministro ${ }^{53}$. Neste sentido, se as visões do Primeiro-Ministro passam a estar em desacordo com as visões do partido que lidera, há uma expectativa de que ele renuncie ao seu cargo, colocando-se um novo líder em seu lugar a critério do partido ${ }^{54}$. De um modo ou de outro, a escolha do Primeiro-Ministro nunca será feita diretamente pelos cidadãos britânicos.

Assim, é possível observar que esse processo lento e gradativo de restrição do poder do monarca, conduzido majoritariamente pelo Parlamento, cujo papel foi definitivamente estabelecido em 1689 com a Revolução Gloriosa, foi o que caracterizou a forma de constitucionalismo adotada pelo Reino Unido até os dias de hoje.

\subsection{Princípios fundamentais da Constituição britânica}

Dada a complexidade do Direito Constitucional britânico e as suas características extremamente peculiares, dificilmente encontradas em outros ordenamentos jurídicos, múltiplos autores britânicos tentaram, em diversas oportunidades, sistematizá-lo.

\footnotetext{
${ }^{53}$ PEMBERTON, Becky. What is a general election, how is the Prime Minister elected and who's allowed to vote in the UK? The Sun, 11 jan. 2018. Disponível em $<$ https://www.thesun.co.uk/uncategorized/3354279/general-election-uk-prime-minister-vote/>. Acesso em 15 nov. 2018.

${ }^{54}$ Foi o que ocorreu, por exemplo, com o ex-Primeiro-Ministro David Cameron, que renunciou ao cargo após o resultado do referendo sobre a saída do Reino Unido da União Europeia. Na sequência, Theresa May se candidatou à liderança do partido que detém a maioria no Parlamento (o Partido Conservador, o mesmo de Cameron). Dois dias após May se tornar a líder do partido, a Rainha Elizabeth II a nomeou como Primeira Ministra, cargo que ocupa até hoje. Para mais informações, cf. PEMBERTON, Becky. Op cit. Disponível em <https://www.thesun.co.uk/uncategorized/3354279/general-election-uk-primeminister-vote/>. Acesso em 15 nov. 2018.
} 
Nesse sentido, A. V. Dicey foi um dos autores responsáveis por decifrar o constitucionalismo inglês - e, possivelmente, o mais prestigiado deles. Em seu livro Introduction to the study of the law of the constitution ${ }^{55}$, Dicey discorre sobre o funcionamento do Direito Constitucional britânico, apontando que este seria composto por três princípios basilares: (i) a soberania parlamentar; (ii) a chamada Rule of Law; e (iii) a relação de dependência entre as convenções e as leis constitucionais ${ }^{56}$. Serão examinados, a seguir, esses três princípios retratados por Dicey.

Em primeiro lugar, a soberania parlamentar, como exposto anteriormente, é reconhecidamente o princípio mais fundamental do direito britânico. No passado, o Rei da Inglaterra era visto como a única fonte de direito e o administrador da ordem ${ }^{57}$, o que era reforçado pela ideia de que "the king can do no wrong". Nesse sentido, a atual importância conferida ao Parlamento inglês decorreu do esvaziamento desses poderes do monarca, definitivamente estabelecido na chamada Revolução Gloriosa de 1688.

Berman sintetiza os seguintes efeitos diretos deste princípio no Direito inglês: (i) o fato de que uma regra criada pelo Parlamento será obrigatoriamente aplicada pelos tribunais; e (ii) o fato de que nenhuma pessoa ou instituição poderá elaborar normas que estejam em desacordo ou tentem abolir atos criados pelo Parlamento inglês ${ }^{58}$.

Vale dizer que tal princípio é tão prestigiado no direito britânico que é o principal motivo de não existir um controle de constitucionalidade propriamente dito (ou um controle "forte" de constitucionalidade) no Reino Unido, tendo surgido o modelo "fraco" de controle apenas no final do século XX.

\footnotetext{
${ }^{55}$ DICEY, Albert Venn. Introduction to the study of the law of the constitution. $8^{\mathrm{a}}$ ed., reimpressão. Londres: $\quad$ Macmillian, $1915 . \quad 584 \quad$ p. $\quad$ Disponível em $<$ http://files.libertyfund.org/files/1714/0125_Bk.pdf>. Acesso em 15 nov. 2018.

${ }^{56}$ DICEY, Albert Venn. Introduction to the study of the law of the constitution. $8^{\mathrm{a}}$ ed., reimpressão. Londres: Macmillian, 1915. p. cxlviii.

${ }^{57}$ Ibid. p. 107.

${ }^{58}$ BERMAN, José Guilherme. Controle fraco de constitucionalidade: sistema jurídico contemporâneo e direito constitucional comparado. Curitiba: Juruá, 2014. p. 96-97.
} 
Em segundo lugar, tem-se a chamada Rule of Law, conceito tão amplo que não possui uma tradução que atenda adequadamente a toda a sua abrangência, mas que poderia ser comparada, em alguns dos seus aspectos, ao conceito de Estado de Direito e, em outros, ao princípio da legalidade ${ }^{59}$.

Dicey elucida que o conceito de Rule of Law abarca três diferentes concepções ${ }^{60}$. A primeira delas é a ideia de que "nenhum homem pode ser punido ou afetado legitimamente em seu corpo ou seus bens, exceto por violação à lei estabelecida perante os tribunais ordinários do país" ${ }^{\prime 61}$, ou seja, a ideia de que a lei é suprema e está acima de todos, não se admitindo o exercício arbitrário por parte do governo na punição de seus governados ${ }^{62}$. Essa concepção, conforme pontua $\operatorname{Berman}^{63}$, se aproximaria ao princípio da legalidade brasileiro, positivado no art. $5^{\circ}$, inciso II, da nossa Constituição ${ }^{64}$.

A segunda concepção da Rule of Law, por outro lado, se relaciona com o conceito de equidade, ou seja, de que todos, independentemente da posição que ocupam, estão sujeitos às leis ordinárias e à jurisdição dos tribunais do Reino Unido $^{65}$.

Esta concepção poderia ser comparada à disposição constante no art. $5^{\circ}$, caput, da Constituição brasileira, qual seja, a de que "[t]odos são iguais perante a lei". Assim, é possível traduzir essa concepção da Rule of Law como princípio da igualdade.

Finalmente, a terceira concepção da Rule of Law, segundo Dicey, é a ideia de que os princípios gerais da Constituição britânica são resultado de decisões

\footnotetext{
${ }^{59}$ Nesse sentido, BERMAN, José Guilherme. Controle fraco de constitucionalidade: sistema jurídico contemporâneo e direito constitucional comparado. Curitiba: Juruá, 2014. p. 92.

${ }^{60}$ DICEY, Albert Venn. Introduction to the study of the law of the constitution. $8^{\mathrm{a}}$ ed., reimpressão. Londres: Macmillian, 1915. p. 110.

${ }^{61}$ DICEY, Albert Venn. Op.cit, tradução livre. No original: "that no man is punishable or can be lawfully made to suffer in body or goods except for a distinct breach of law established in the ordinary legal manner before the ordinary Courts of the land'.

${ }^{62}$ DICEY, Albert Venn. Op.cit. p. 120.

${ }^{63}$ BERMAN, José Guilherme. Op.cit. p. 97-98.

64 “[N]inguém será obrigado a fazer ou deixar de fazer alguma coisa senão em virtude de lei"

${ }^{65}$ DICEY, Albert Venn. Op.cit. p. 114.
} 
judiciais que declararam os direitos individuais em casos concretos ${ }^{66}$. Para o autor, a Constituição britânica seria, então, feita por juízes ${ }^{67}$, e não originada por um ato legislativo prévio.

Dessa forma, as normas da Constituição britânica não seriam nada mais do que uma mera generalização dos direitos que já são historicamente assegurados aos indivíduos pelos tribunais britânicos ${ }^{68}$. Pode se dizer, portanto, que a Constituição não é uma fonte de direitos individuais, e sim uma consequência desses direitos, que são definidos e aplicados pelas cortes ${ }^{69}$.

Ressalte-se que, neste caso, a concepção de Dicey da Rule of Law se apresenta como o exato oposto do que ocorre no direito brasileiro, uma vez que a regra no Brasil é que haja uma norma prévia, proveniente de um ato do Legislativo, que será posteriormente aplicada e interpretada pelos tribunais brasileiros, e não o contrário. Apesar disso, poderíamos comparar essa concepção da Rule of Law ao conceito de Estado de Direito existente no direito brasileiro.

Questiona-se, então, se não haveria a possibilidade desses dois princípios - o da Rule of Law e o da soberania parlamentar - entrarem em conflito. Neste sentido, elucida Fitzgerald sobre como deve se dar a relação entre eles:

\footnotetext{
"Assim, enquanto a soberania parlamentar permanece como a principal característica distintiva da constituição não escrita da Grã-Bretanha, a observância da "rule of law" é reconhecida como um princípio constitucional fundamental derivado da common law e compreendido como parte do pano de fundo em relação à qual a legislação parlamentar deve ser mensurada."
}

\footnotetext{
${ }^{66}$ Ibid. p. 115.

${ }^{67}$ Conforme DICEY, Albert Venn. Introduction to the study of the law of the constitution. $8^{\mathrm{a}}$ ed., reimpressão. Londres: Macmillian, 1915. p. 116: "Our constitution, in short, is a judge-made constitution".

${ }^{68}$ DICEY, Albert Venn. Op.cit. p. 119.

${ }^{69}$ Ibid. p. 121.

${ }^{70}$ FITZGERALD, Peter L., Constitutional crisis over the proposed Supreme Court for the United Kingdom. Temple International \& Comparative Law Journal, v. 18, 2004. p. 254, tradução livre. No original: "Thus, while parliamentary sovereignty remains the key distinguishing feature of Britain's unwritten constitution, observance of the "rule of law" is itself recognized as a fundamental constitutional principle derived from the common law and comprising part of the background against
} 
Por fim, há a relação entre as convenções constitucionais e as leis constitucionais. As leis constitucionais, segundo Dicey, consistem nas regras aplicadas e reconhecidas pelos tribunais; enquanto as convenções constitucionais consistem em costumes, práticas, máximas ou preceitos que não são aplicáveis pelos tribunais, sendo dotados meramente de natureza política ${ }^{71}$.

As convenções constitucionais são, em suma, regras destinadas a regular o exercício dos poderes discricionários da Coroa, sejam eles exercidos pelo próprio Rei ou pelo Primeiro-Ministro.

As convenções se tratam de regras que determinam a forma de exercício do poder político, como, por exemplo, (i) as funções do Primeiro-Ministro, do Gabinete e do Monarca; (ii) o próprio cargo de Primeiro-Ministro, cuja primeira referência em texto legal só ocorreu em 1937; ou (iii) o não exercício do direito de veto pelo monarca ${ }^{72}$.

Deste modo, os atos que o Poder Executivo pode praticar não decorrem de leis elaboradas pelo Parlamento, mas sim de prerrogativas, cujo modo de exercício é determinado por convenções historicamente constituídas e sistematicamente obedecidas. Frise-se que, apesar dessas convenções não serem juridicamente coercíveis, não sendo possível, por exemplo, o ajuizamento de uma ação judicial para garantir o seu cumprimento, há no Reino Unido uma "justa expectativa da população e dos próprios governantes de que elas serão respeitadas $"$ "73.

Neste ponto, as formas de garantia historicamente reconhecidas para o cumprimento dessas convenções, segundo Dicey, seriam (i) a ameaça de

which parliamentary legislation must be measured." Disponível em $<\mathrm{https}: / /$ ssrn.com/abstract=643801 $>$. Acesso em 15 nov. 2018.

${ }^{71}$ DICEY, Albert Venn. Introduction to the study of the law of the constitution. Reprint. Originally published: $8^{\mathrm{a}}$ ed. London: Macmillian, 1915, p. 277.

${ }^{72}$ BARROSO, Luís Roberto. Curso de direito constitucional contemporâneo: os conceitos fundamentais e a construção do novo modelo. $2^{\mathrm{a}}$ ed.. São Paulo: Saraiva, 2010. p. 13.

${ }^{73}$ BERMAN, José Guilherme. Controle fraco de constitucionalidade: sistema jurídico contemporâneo e direito constitucional comparado. Curitiba: Juruá, 2014. p. 112. 
impeachment que se impõe à autoridade que as descumprir; e (ii) a possibilidade de deixarem de ser eleitos os políticos que descumprirem essas máximas da moralidade política nas eleições subsequentes.

Para o autor, no entanto, essas duas opções não seriam suficientes para garantir o status de obrigatoriedade que as convenções constitucionais possuem no ordenamento jurídico britânico. A conclusão a que Dicey chega é que as convenções constitucionais seriam impostas, portanto, pela "força do direito" ${ }^{\text {"74 }}$.

\subsection{0 novo modelo de constitucionalismo da Commonwealth}

Exposto o panorama da concepção tradicional do constitucionalismo britânico e suas principais características, será feita a seguir uma breve exposição sobre o novo modelo de constitucionalismo da Commonwealth, suscitada pelo autor Stephen Gardbaum ${ }^{75}$.

Segundo Gardbaum, esse novo modelo se caracterizaria por ser intermediário, pois transcenderia a dicotomia supremacia judicial versus supremacia legislativa e asseguraria de modo formal e legal as garantias aos direitos individuais, distanciando-se do modelo tradicional de constitucionalismo da supremacia legislativa adotada pelos países da Commonwealth $^{76}$. Conforme se verá adiante, esse fenômeno pôde ser percebido no Canadá, na Nova Zelândia e no Reino Unido.

Esse novo modelo, ainda segundo Gardbaum, não seria inspirado no modelo americano - no qual é conferido um vasto poder ao Judiciário no que

\footnotetext{
${ }^{74}$ BERMAN, José Guilherme. Controle fraco de constitucionalidade: sistema jurídico contemporâneo e direito constitucional comparado. Curitiba: Juruá, 2014. p. 112-113. Nesse sentido, DICEY, Albert Venn. Introduction to the study of the law of the constitution. $8^{\mathrm{a}}$ ed., reimpressão. Londres: Macmillian, 1915. p. 296: "[...] the conventions of the constitution are supported and enforced by something beyond or in addition to the public approval. What then is this "something"? My answer is, that it is nothing else than the force of the law".

${ }^{75}$ GARDBAUM, Stephen. The New Commonwealth Model of Constitutionalism. American Journal of Comparative Law, v. 49, 2001. p. 707-760.

${ }^{76}$ Ibid. p. 760 .
} 
tange à interpretação da Constituição ${ }^{77}$-, mas seria um modelo inédito, no qual, enquanto se concede às cortes um maior poder para aplicar os direitos fundamentais, desassocia o judicial review da supremacia judicial ao delegar ao Legislativo o poder da palavra final na aplicação desses direitos ${ }^{78}$.

O modelo americano, por outro lado, por ter sido concebido no contexto da conquista da independência dos Estados Unidos como colônia da Inglaterra, tentou se distanciar ao máximo do modelo deste país, qual seja, o da supremacia parlamentar.

A premissa do sistema americano é que o poder Legislativo é legalmente limitado, delegando-se aos tribunais o poder de colocar esses limites em prática $^{79}$. Esse modelo também é baseado na ideia da supremacia da Constituição - devendo esta prevalecer na ocasião de se haver conflitos com leis federais ou estaduais -, além de na noção de que a Constituição é rígida, no sentido de que só pode ser emendada através de procedimento legislativo específico ${ }^{80}$.

Este modelo foi amplamente adotado por diversos países no contexto pós $2^{\text {a }}$ Guerra Mundial, como, por exemplo, pela Alemanha (1949), Itália (1948), Japão (1947) e Portugal (1982), tendo em vista o fracasso do modelo constitucional de supremacia legislativa na prevenção da ascensão de regimes totalitários $^{81}$. Esse fator justificou a adoção de uma Constituição em um documento único nesses e em outros países, na qual são garantidos expressamente os direitos fundamentais dos cidadãos, conferindo-se aos tribunais o papel de protegê- $\operatorname{los}^{82}$.

\footnotetext{
${ }^{77}$ GARDBAUM, Stephen. The New Commonwealth Model of Constitutionalism. American Journal of Comparative Law, v. 49, 2001. p. 710.

${ }^{78}$ Ibid. p. 760.

${ }^{79}$ Ibid. p. 711.

${ }^{80}$ É de se registrar que, desde a edição da Constituição americana, em 1789, 33 emendas foram propostas pelo Congresso e somente 27 foram aprovadas na forma do seu art. $5^{\circ}$, o que demonstra o seu caráter de excepcionalidade. Para fins de comparação, a Constituição brasileira, também dotada de rigidez e promulgada há apenas 30 anos, já possui 99 emendas constitucionais em vigor.

${ }^{81}$ GARDBAUM, Stephen. Op.cit. p. 714-715.

${ }^{82}$ Cumpre destacar que, distanciando-se do modelo americano, alguns países europeus optaram pela adoção de um modelo de controle constitucional concentrado, no qual é concedido a um único tribunal o poder de exercer esse controle (chamado por alguns autores de "modelo austríaco" de controle de
} 
Em contraposição à Constituição americana e a dos países que a seguiram, estaria o modelo tradicional britânico, que possui como premissa maior a soberania do Parlamento, o que significa, na prática, que os tribunais não têm poder de questionar a validade dos atos do Parlamento, que são considerados como a lei suprema do Estado ${ }^{83}$.

No entanto, países integrantes da Commonwealth, notadamente Canadá, Nova Zelândia e Reino Unido - os quais, tradicionalmente, foram conhecidos por adotar o modelo de supremacia do Legislativo -, começaram, no final do século XX, a adotar medidas para amparar melhor os direitos fundamentais.

Diversamente do modelo americano, neste novo modelo foi recusada a ideia de se conferir ao Judiciário a última palavra na aplicação dos direitos fundamentais. Foi, assim, criado o que Gardbaum chamou de "novo modelo de constitucionalismo da Commonwealth", que se caracterizaria por ser um meio termo entre uma declaração de direitos plenamente constitucionalizada (modelo americano) e uma plena supremacia do legislativo (modelo tradicional da Commonwealth) $)^{84}$.

Representaram a mudança de paradigma nesses três países, respectivamente, a Charter of Rights and Freedoms canadense ${ }^{85}$, de 1982; o Bill of Rights Act da Nova Zelândia ${ }^{86}$, de 1990; e o Human Rights Act britânico ${ }^{87}$, de 1998.

A criação dessas declarações de direitos rejeitou a ideia de que a supremacia do Legislativo e a proteção dos direitos fundamentais seriam mutuamente exclusivos, uma vez que garantem uma proteção judicial dos

constitucionalidade). Veja-se, nesse sentido, o capítulo 1 deste trabalho, além de GARDBAUM, Stephen. The New Commonwealth Model of Constitutionalism. American Journal of Comparative Law, v. 49, 2001. p. 717.

${ }_{84}^{83}$ GARDBAUM, Stephen. Op.cit. p. 713.

${ }^{84}$ Ibid. p. 719.

${ }^{85}$ Ibid.

${ }^{86}$ Ibid. p. 727.

${ }^{87}$ Ibid. p. 732 . 
direitos fundamentais ao mesmo tempo que deixam com o Legislativo a garantia de que terão a última palavra no que diz respeito ao Direito ${ }^{88}$.

Veja-se o caso do Reino Unido, por exemplo. O Human Rights Act previu, de forma inédita no direito britânico, os seguintes mecanismos: (i) a possibilidade de ser emitida uma declaração de incompatibilidade pelos tribunais britânicos, revelando uma incompatibilidade da legislação ordinária em relação às normas nele previstas (seção 4 do Human Rights Act); e (ii) a existência de uma obrigação interpretativa, que consistiria em um dever das cortes britânicas de tentarem, ao máximo, interpretar as leis nacionais em acordo com os direitos nele previstos (seção 3 do Human Rights Act) ${ }^{89}$. Observa-se, assim, que foi reconhecido pelo próprio Human Rights Act um caráter de superioridade dos direitos que nele constam em relação à legislação ordinária.

É de se destacar, ainda, que, até mesmo as leis constitucionais seculares do Reino Unido nunca previram qualquer tipo de instituto que se aproxime da declaração de incompatibilidade ou da obrigação interpretativa. Demonstra-se, dessa forma, que, o Human Rights Act foi responsável por conferir às cortes britânicas um poder sem precedentes na História constitucional do Reino Unido, tendo sido chamado, inclusive, de "uma reviravolta na história legal e constitucional do Reino Unido" ${ }^{\text {" }}$.

Gardbaum, quase 10 anos após a publicação do primeiro artigo aqui mencionado - no qual sugere um novo modelo de constitucionalismo da Commonwealth -, faz uma reavaliação deste modelo na prática, concluindo que foi razoavelmente bem-sucedido em promover uma proteção aos direitos

\footnotetext{
${ }^{88}$ GARDBAUM, Stephen. The New Commonwealth Model of Constitutionalism. American Journal of Comparative Law, v. 49, 2001. p. 741-742.

${ }^{89}$ Entraremos mais em mais detalhes sobre ambos os institutos no próximo capítulo.

${ }^{90}$ Segundo LESTER. The impact of the Human Rights Act on Public Law. In: Constitutional reform in the United Kingdom: Practices and principles, 1998 (apud GARDBAUM, Stephen. Op.cit. p. 732), tradução livre. No original: "a turning point in the UK's legal and constitutional history".
} 
adequada e uma balanceada alocação dos poderes governamentais, limitando tanto o Judiciário quanto o Legislativo ${ }^{91}$.

No caso específico do Reino Unido, Gardbaum pondera que, na prática, o Human Rights Act se apresentou entre uma medida "muito potente" e "suficientemente boa"92 (sic) na proteção dos direitos fundamentais.

Em defesa do argumento de que o Human Rights Act teria se mostrado muito potente, Gardbaum expõe que, em alguns casos (como no caso dos prisioneiros de Belmarsh, que será debatido no capítulo seguinte), as declarações de incompatibilidade geraram intensos e prolongados debates no Parlamento, além de respostas afirmativas no sentido de alterar a legislação incompatível para que passasse a estar em consonância com essas declarações ${ }^{93}$.

Ao mesmo tempo, a edição do Human Rights Act se mostrou suficientemente boa, na medida em que criou uma maior consciência sobre os direitos, seja entre os cidadãos, os tribunais, o Parlamento ou o governo, tornando-os mais conhecidos, além de ter ampliado o rol de direitos legalmente reconhecidos $^{94}$, algo que nem sempre tem a sua importância devidamente reconhecida em um país que adota o sistema da common law, no qual as decisões judiciais também fazem parte da produção primária de normas.

Ressalta-se aqui, por fim, que, apesar de não ter sido mencionado por Gardbaum em nenhum dos dois artigos supracitados, pode se dizer que a criação da Suprema Corte britânica pelo Constitutional Reform Act em 2005 também foi representativa dessa mudança de paradigma do constitucionalismo da Commonwealth no Reino Unido, uma vez que, além de criar uma Suprema Corte britânica, a instituiu como última instância do Judiciário britânico, papel que era,

\footnotetext{
91 GARDBAUM, Stephen. Reassessing The New Commonwealth Model of Constitutionalism. International Journal of Constitutional Law, v. 8, n. 2, 2010. p. 205.

92 Ibid. p. 191.

93 Ibid. p. 192.

94 Ibid. p. 198.
} 
anteriormente, exercido pela House of Lords, uma das casas do Parlamento ${ }^{95}$, fato que deixava evidente a dependência daquela instituição em relação a esta. Assim, a criação da Suprema Corte reforçou a nova direção tomada pelo Estado britânico de se conferir mais poderes e maior independência ao Judiciário, atenuando o tão estimado princípio da soberania parlamentar e dando uma maior proteção aos cidadãos contra o uso do poder arbitrário do governo ${ }^{96}$, de modo a aumentar a confiança da população e da comunidade internacional nas instituições britânicas ${ }^{97}$.

${ }^{95}$ FITZGERALD, Peter L., Constitutional crisis over the proposed Supreme Court for the United Kingdom. Temple International \& Comparative Law Journal, v. 18, 2004. p. 233.

${ }^{96}$ WOODHOUSE, Diana. The Constitutional Reform Act 2005: defending judicial independence the English way. International Journal of Constitutional Law, v. 5, jan. 2007. p. 156, Disponível em $<$ https://doi.org/10.1093/icon/mol039>. Acesso em 15 nov. 2018.

${ }^{97}$ FITZGERALD, Peter L., Op.cit. p. 267. 


\section{Capítulo 3 - O controle fraco de constitucionalidade no Reino Unido}

\subsection{O Human Rights Act de 1998}

O sistema de controle de constitucionalidade britânico, por muito tempo, foi caracterizado pela ausência de fiscalização da constitucionalidade das normas pelo poder Judiciário ${ }^{98}$, cabendo apenas ao Parlamento revogar qualquer lei, caso viesse a entender que haveria uma incompatibilidade entre uma norma e os princípios e leis constitucionais britânicos.

Historicamente, o poder de judicial review das cortes britânicas se limitou à restrição do exercício do poder executivo ou administrativo para além do conferido pela legislação ${ }^{99}$, mas nunca no sentido de restringir de qualquer forma a atividade legislativa.

No entanto, no final do século XX, este sistema sofreu uma considerável transformação, pois passou a permitir uma forma de controle de constitucionalidade pelo Judiciário. $\mathrm{O}$ marco dessa transformação foi a edição do Human Rights Act 1998 ("HRA"), que entrou em vigor em 20 de outubro de $2000^{100}$.

O objetivo precípuo desta lei foi incorporar ao direito britânico as

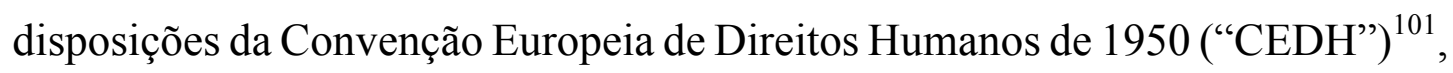
criada pela extinta Comunidade Europeia (cuja função é desempenhada hoje pela União Europeia).

\footnotetext{
${ }^{98}$ BINENBOJM, Gustavo. A nova jurisdição constitucional: Legitimidade democrática e instrumentos de realização. $4^{\mathrm{a}}$ ed. revista, ampliada e atualizada. Rio de Janeiro: Renovar, 2014. p. 42.

${ }^{99}$ FITZGERALD, Peter L., Constitutional crisis over the proposed Supreme Court for the United Kingdom. Temple International \& Comparative Law Journal, v. 18, 2004. p. 245.

${ }^{100}$ GARDBAUM, Stephen. The New Commonwealth Model of Constitutionalism. American Journal of Comparative Law, v. 49, 2001. p. 732.

${ }^{101}$ Ibid.
} 
A incorporação desta Convenção através do Human Rights Act foi chamada pela mídia e pelos juristas de "bringing rights home"102, expressão cuja tradução literal seria "trazendo os direitos para casa". Bellamy narra que o uso dessa expressão se deu em razão da oferta de remédios legais nacionais de proteção aos direitos humanos, na tentativa de redução da necessidade de se recorrer à Corte Europeia de Direitos Humanos ("CtEDH”) quando houvesse qualquer violação à $\mathrm{CEDH}$, uma vez que (i) as condenações de tribunais domésticos seriam menos embaraçosas para o Reino Unido do que as condenações de cortes estrangeiras; e (ii) as decisões dos tribunais britânicos estariam mais em sintonia com o modo de pensar e as tradições britânicas como, por exemplo, a própria ideia de constitucionalismo político ${ }^{103}$.

Nota-se que a necessidade de internalização da CEDH se tornou mais urgente diante das sucessivas condenações do Reino Unido perante a Corte Europeia de Direitos Humanos, sobretudo em casos relacionados a medidas tomadas pelo Reino Unido com relação ao combate ao terrorismo ${ }^{104}$ - o que gerava prejuízos não só para a sua imagem diante da comunidade internacional, como também para os cofres públicos, pois muitas das condenações da CtEDH consistiam em altas compensações em dinheiro.

Como as prévias tentativas do Reino Unido de consolidação de direitos fundamentais em um documento único, dotado de supremacia - de forma a impedir a sua posterior revogação pelo Parlamento -, haviam fracassado diante da força do princípio da soberania parlamentar, o legislador do HRA se esquivou de enfrentar essa questão, aprovando o Human Rights Act como uma lei comum, confiando que as eventuais novas maiorias do Parlamento compreenderiam a

\footnotetext{
102 BELLAMY, Richard. Political constitutionalism and the Human Rights Act. International Journal of Constitutional Law, v. 9, jan. 2011. p. 89. Disponível em <https://doi.org/10.1093/icon/mor024>. Acesso em 15 nov. 2018.

103 Ibid. p. 96.

104 FITZGERALD, Peter L., Constitutional crisis over the proposed Supreme Court for the United Kingdom. Temple International \& Comparative Law Journal, v. 18, 2004. p. 246.
} 
importância da internalização desses direitos e não revogariam o HRA posteriormente $^{105}$.

Para além da positivação de diversos direitos fundamentais, será analisado, a seguir, o papel exercido pelo Human Rights Act na consolidação de uma forma mais branda de controle jurisdicional no Reino Unido, através da criação de dois institutos.

O primeiro deles é a chamada obrigação interpretativa, prevista na seção 3 do HRA ${ }^{106}$. O HRA prevê que os tribunais britânicos devem tentar, sempre que possível, interpretar as leis britânicas de acordo com os direitos previstos nele e na CEDH.

Deste modo, a obrigação interpretativa poderia ser comparada com a interpretação conforme a Constituição do direito brasileiro, segundo a qual, havendo mais de uma interpretação possível a uma norma, deve-se adotar a que se mostre mais compatível com a Constituição - o que pode, em contraposição, gerar também a chamada declaração de inconstitucionalidade sem redução de texto, instrumento utilizado pelo STF para declarar que determinada interpretação de uma norma é incompatível com a Constituição, vedando o seu uso em detrimento de outra mais compatível com as normas constitucionais ${ }^{107}$.

Um dos casos mais conhecidos em que o Judiciário britânico fez uso da obrigação interpretativa, foi o Ghaidan $v$ Godin-Mendoza ${ }^{108}$. A questão principal deste caso envolvia a possibilidade de um parceiro do mesmo sexo

\footnotetext{
${ }^{105}$ FITZGERALD, Peter L., Constitutional crisis over the proposed Supreme Court for the United Kingdom. Temple International \& Comparative Law Journal, v. 18, 2004. p. 247.

${ }^{106}$ Seção 3(1) do Human Rights Act: "So far as it is possible to do so, primary legislation and subordinate legislation must be read and given effect in a way which is compatible with the Convention rights."

${ }^{107}$ MENDES, Gilmar Ferreira. Curso de direito constitucional. $11^{\mathrm{a}}$ ed.. São Paulo: Saraiva, 2016. p. 1.346-1.347.

${ }^{108}$ Caso Ghaidan v Godin-Mendoza [2002] EWCA Civ 1533; [2004] UKHL 30, julgado em 21 jun. $2004 . \quad$ Íntegra da decisão disponível em $<$ https://publications.parliament.uk/pa/ld200304/ldjudgmt/jd040621/gha-1.htm>. Acesso em 15 nov. 2018.
} 
suceder a um arrendamento celebrado pelo parceiro falecido com base no Rent Act $1977^{109}$.

A controvérsia se devia ao fato de que o parágrafo 2(1) do First Schedule ${ }^{110}$ desta lei previa o direito sucessório do arrendamento ao "cônjuge sobrevivente", sendo cônjuge definido pelo parágrafo 2(2) deste mesmo Schedule ${ }^{111}$ como "a pessoa que estava vivendo com o inquilino originário como sua esposa ou seu marido". A questão era, portanto, se um parceiro do mesmo sexo se encaixaria na definição de cônjuge do parágrafo 2(2).

É de se registrar que, em um caso anterior à vigência do HRA, a House of Lords já havia entendido que os parceiros do mesmo sexo não se encaixariam nessa definição ${ }^{112}$. No entanto, em Ghaidan v Godin-Mendoza, decidido já na vigência do HRA, a mesma Corte entendeu que a interpretação anterior violaria os artigos 8 e 14 da CEDH, que garantem, respectivamente, o direito ao respeito ao lar da pessoa e o direito à não discriminação ${ }^{113}$.

Assim, utilizando-se da obrigação interpretativa, a House of Lords concluiu que havia uma interpretação não-discriminatória passível de ser adotada no caso em tela, passando-se a permitir que um parceiro do mesmo sexo sucedesse o parceiro falecido em um arrendamento celebrado por este ${ }^{114}$.

Por outro lado, quando não for possível fazer uso da obrigação interpretativa, ou seja, quando a lei britânica analisada violar de forma tão

\footnotetext{
${ }^{109}$ SMIT, Jan van Zyl. The New Purposive Interpretation of Statutes: HRA Section 3 after Ghaidan v Godin-Mendoza. The Modern Law Review, v. 70, fev. 2007. p. 297. Disponível em $<$ https://doi.org/10.1111/j.1468-2230.2007.00638.x>. Acesso em 15 nov. 2018.

${ }^{110}$ Parágrafo 2(1) do First Shedule do Rent Act 1977 (redação anterior a 05 dez. 2005): "The surviving spouse (if any) of the original tenant, if residing in the dwelling-house immediately before the death of the original tenant, shall after the death be the statutory tenant if and so long as he or she occupies the dwelling-house as his or her residence."

${ }^{111}$ Parágrafo 2(2) do First Shedule do Rent Act 1977 (redação anterior a 05 dez. 2005): "For the purposes of this paragraph, a person who was living with the original tenant as his or her wife or husband shall be treated as the spouse of the original tenant."

${ }_{112}$ O caso mencionado é o Fitzpatrick v Sterling Housing Association [2001] 1 AC 27, julgado em 28 out. $1999 . \quad$ Íntegra da decisão disponível em $<$ https://publications.parliament.uk/pa/ld199899/ldjudgmt/jd991028/fitz01.htm>. Acesso em 15 nov. 2018. Nesse sentido, cf. SMIT, Jan van Zyl. Op.cit. p. 297.

${ }^{113}$ SMIT, Jan van Zyl. Op.cit. p. 298.

${ }^{114}$ Ibid. p. 298.
} 
evidente o Human Rights Act que não haja nenhuma possível interpretação à norma que a faça estar em compatibilidade com as normas nele previstas, os tribunais poderão fazer uso do segundo instituto criado pelo Human Rights Act, qual seja, a chamada declaração de incompatibilidade, prevista na seção 4 do $\mathrm{HRA}^{115}$. Essa medida, portanto, deve ser utilizada de forma excepcional, priorizando-se sempre o uso da obrigação interpretativa ${ }^{116}$.

Abre-se aqui um parêntese. A obrigação interpretativa, como o próprio nome diz, é uma obrigação que se impõe a todos os tribunais britânicos, enquanto a declaração de incompatibilidade, por outro lado, como é uma prerrogativa dos magistrados, caracteriza-se por ter uma forma concentrada, só podendo ser emitida por alguns dos tribunais e cargos mais altos do Judiciário britânico, pré-determinados pela seção 4(5) do HRA ${ }^{117}$.

Mesmo se tratando de medida excepcional, a declaração de incompatibilidade não permite que o Judiciário anule determinada norma ou deixe de aplicá-la, nem é vinculante para as partes do processo em que ela é emitida, nos termos da seção 4(6) do HRA ${ }^{118}$. Ela tem por fim a mera sinalização ao Parlamento de uma incompatibilidade da norma britânica com determinado direito previsto no HRA e na $\mathrm{CEDH}^{119}$. Assim, cabe somente ao Parlamento decidir pela revogação ou alteração da norma declarada incompatível, valendo a declaração de incompatibilidade apenas como um instrumento de pressão política.

\footnotetext{
${ }^{115}$ Seção 4(2) do Human Rights Act: "If the court is satisfied that the provision is incompatible with a Convention right, it may make a declaration of that incompatibility."

${ }^{116}$ FITZGERALD, Peter L., Constitutional crisis over the proposed Supreme Court for the United Kingdom. Temple International \& Comparative Law Journal, v. 18, 2004. p. 247.

${ }^{117}$ São eles: a Supreme Court, o Judicial Committee of the Privy Council, a Court Martial Appeal Court, a High Court of Justiciary escocesa, as High Courts ou Courts of Appeal da Inglaterra, País de Gales e Irlanda do Norte, a Court of Protection, o Chancellor ou qualquer juiz da High Court.

118 Seção 4(6) do Human Rights Act: "A declaration under this section ("a declaration of incompatibility")-

(a) does not affect the validity, continuing operation or enforcement of the provision in respect of which it is given; and

(b) is not binding on the parties to the proceedings in which it is made."

${ }^{119}$ FITZGERALD, Peter L., Op.cit. p. 247.
} 
Digno de nota que, como o Judiciário não pode deixar de aplicar a lei que considera incompatível com o HRA, é possível que ele forneça algum outro tipo de remédio ou compensação pela ilegalidade do ato do governo ${ }^{120}$, tal como a condenação do governo ao pagamento de perdas e danos, nos termos da seção 8 do HRA ${ }^{121}$.

Assim, sobre os instrumentos criados pelo Human Rights Act, conclui Fitzgerald que "o HRA orienta os tribunais a aplicar a CEDH e a lei europeia conexa de forma afirmativa, enquanto tenta, ao mesmo tempo, preservar o papel proeminente do Parlamento no sistema constitucional britânico" ${ }^{\text {122 }}$.

O que se observa, portanto, é que o HRA concedeu ao Judiciário um poder político que ele nunca antes possuiu, qual seja, o de formalmente pressionar o Parlamento a alterar uma lei incompatível com os direitos nele previstos, representando uma transferência inédita naquele país de alguns poderes políticos do Executivo e Legislativo ao Judiciário ${ }^{123}$, e conferindo um maior equilíbrio ao sistema de freios e contrapesos britânico - ao mesmo tempo que se mantém a última palavra sobre as leis com o Parlamento, preservando o princípio da soberania parlamentar, tão fundamental para o direito britânico.

De tal forma, podemos dizer que o Reino Unido adotou um modelo de controle de constitucionalidade mais brando, chamado por alguns autores de controle "fraco" de constitucionalidade ${ }^{124}$ ou weak-form judicial review ${ }^{125}$, uma vez que, apesar de admitir que juízes declarem a inconstitucionalidade de

${ }^{120}$ FITZGERALD, Peter L., Constitutional crisis over the proposed Supreme Court for the United Kingdom. Temple International \& Comparative Law Journal, v. 18, 2004. p. 247.

${ }^{121}$ Seção 8(1) do Human Rights Act: "In relation to any act (or proposed act) of a public authority which the court finds is (or would be) unlawful, it may grant such relief or remedy, or make such order, within its powers as it considers just and appropriate."

${ }^{122}$ FITZGERALD, Peter L., Op.cit, tradução livre. No original: "Thus, the HRA affirmatively directs the courts to apply the ECHR and related European law, while at the same time attempting to preserve Parliament's preeminent role in the British constitutional system."

${ }^{123}$ FITZGERALD, Peter L., Op.cit. p. 248.

${ }^{124}$ BERMAN, José Guilherme. Controle fraco de constitucionalidade: sistema jurídico contemporâneo e direito constitucional comparado. Curitiba: Juruá, 2014. p. 177.

${ }^{125}$ TUSHNET, Mark V. New Forms of Judicial Review and the Persistence of Rights - And DemocracyBased Worries. Georgetown Law Faculty Publications and Other Works, 2003. p. 814. Disponível em $<$ https://scholarship.law.georgetown.edu/facpub/247>. Acesso em 15 nov. 2018. 
determinada norma, não permite a anulação ou o afastamento da aplicação da lei pelo Judiciário, possuindo este, assim, "uma palavra em matéria de controle de constitucionalidade, mas não necessariamente a última"126.

Além disso, conforme pontuado por Berman, o modelo de judicial review britânico tem como parâmetro apenas o Human Rights Act e a Convenção Europeia de Direitos Humanos - e não as leis e princípios constitucionais tradicionais -, não podendo se dizer com absoluta certeza que se trata de um controle de constitucionalidade propriamente dito, já que "o parâmetro de aferição de compatibilidade é distinto do que comumente ocorre" $" 127$.

Apesar disso, o que se observa é que a forma de controle adotada pelo Reino Unido tem tido razoável sucesso em pressionar o Parlamento a alterar a legislação, como se verá no caso exposto a seguir, um dos mais discutidos no âmbito do Direito Constitucional britânico moderno.

\subsection{O caso dos prisioneiros de Belmarsh}

O atentado terrorista ao World Trade Center, ocorrido em 11 de setembro de 2001 em Nova York, nos Estados Unidos, gerou uma mudança radical no contexto político mundial e nas exigências atinentes à segurança nacional em relação à ameaça terrorista ${ }^{128}$ - especialmente nas maiores potências ocidentais.

Esse temor levou, por exemplo, o Parlamento britânico a editar o Antiterrorism, Crime and Security Act 2001, aprovado apenas dois meses após a ocorrência do atentado. A seção 23 da parte 4 desta lei ${ }^{129}$ permitia que o Home

\footnotetext{
${ }^{126}$ BERMAN, José Guilherme. Controle fraco de constitucionalidade: sistema jurídico contemporâneo e direito constitucional comparado. $1^{\text {a }}$ ed. - Curitiba: Juruá, 2014, p. 120.

${ }^{127}$ Ibid. p. 174.

${ }^{128}$ Nesse sentido, cf. UDICE, Kristina. 10 ways the world changed after the 9/11 attacks. Insider, 10 set. 2018. Disponível em <https://www.thisisinsider.com/world-changed-after-september-11-2018-9>. Acesso em 15 nov. 2018.

129 " 23 Detention

(1) A suspected international terrorist may be detained under a provision specified in subsection (2) despite the fact that his removal or departure from the United Kingdom is prevented (whether temporarily or indefinitely) by-
} 
Secretary of State, determinasse, através da emissão de um certificado, a prisão cautelar de estrangeiros por suspeita de atos terroristas por tempo indeterminado, sem a observância do devido processo legal e sem nenhum tipo de condenação $^{130}$, nos casos em que não fosse possível a deportação do suspeito ${ }^{131}$.

Utilizando-se desta prerrogativa, o Home Secretary da época, David Blunkett, determinou a detenção de 9 muçulmanos suspeitos de terrorismo na prisão de segurança máxima de Belmarsh, sem acesso às provas produzidas contra eles e presos em suas celas 22 horas por dia ${ }^{132}$.

Os estrangeiros, então, recorreram ao Judiciário inglês, alegando violação ao direito à liberdade, previsto no artigo $5^{\circ}$ do $\mathrm{CEDH}$, e ao direito de não discriminação, previsto no art. 14 da Convenção, uma vez que a lei que permitia a prisão por tempo indeterminado se aplicava apenas a suspeitos estrangeiros.

O Home Secretary alegou que a situação se enquadraria no art. 15 da CEDH, que permite a derrogação dos direitos previstos na Convenção em momentos de guerra ou outra emergência pública que ameace a vida da nação, desde que essa derrogação seja necessária e proporcional à ameaça ${ }^{133}$. Segundo o Estado, o temor gerado pelo 11 de setembro se enquadraria no conceito de emergência pública que ameaça a vida da nação.

(a) a point of law which wholly or partly relates to an international agreement, or (b) a practical consideration."

130 JENKINS, David. Citizenship and the Limits of Due Process since 9/11. In: JENKINGS, David; JACOBSEN, Amanda; HENRIKSEN, Anders (Org.). The Long Decade: How 9/11 Changed the Law. Oxford University Press, 2014. p. 179. Disponível em $<$ https://ssrn.com/abstract=2319443>. Acesso em 15 nov. 2018.

${ }^{131}$ No caso Chahal v. United Kingdom, por exemplo, julgado pela Corte Europeia de Direitos Humanos, foi determinado que a deportação de um estrangeiro seria proibida caso houvesse risco de tortura no seu país de origem (JENKINS, David. Citizenship and the Limits of Due Process since 9/11. In: JENKINGS, David; JACOBSEN, Amanda; HENRIKSEN, Anders (Org.). Op.cit. p. 179).

${ }^{132}$ WINTERMAN, Denise. Belmarsh - Britain's Guantanamo Bay? BBC News, 6 out. 2004. Disponível em $<$ http://news.bbc.co.uk/2/hi/uk_news/magazine/3714864.stm>. Acesso em 15 nov. 2018.

133 "ARTIGO $15^{\circ}$ - Derrogação em caso de estado de necessidade

1. Em caso de guerra ou de outro perigo público que ameace a vida da nação, qualquer Alta Parte Contratante pode tomar providências que derroguem as obrigações previstas na presente Convenção, na estrita medida em que o exigir a situação, e em que tais providências não estejam em contradição com as outras obrigações decorrentes do direito internacional." 
O caso chegou à última instância do Judiciário inglês - à época, a House of Lords, papel que atualmente é exercido pela Suprema Corte, criada pelo Constitutional Reform Act 2005 -, tendo sido julgado em 16 de dezembro de $2004^{134}$.

Dos 9 Law Lords que integravam a Corte, 8 decidiram que, de fato, o temor causado pelos atentados terroristas recentes poderia ser classificado como emergência pública. Neste ponto, o único voto divergente foi o de Lord Hoffmann, que entendeu que o terrorismo, apesar de apresentar uma ameaça aos indivíduos, não seria propriamente uma ameaça às instituições governamentais ou à existência do Reino Unido como uma comunidade, não podendo ser enquadrado como uma ameaça à vida da nação ${ }^{135}$.

No entanto, dos 8 Law Lords que votaram pela aplicação do art. 15 da CEDH, 7 entenderam que a sanção adotada seria desproporcional diante da ameaça existente, declarando que a seção 23 do Anti-terrorism, Crime and Security Act 2001 seria incompatível com o HRA e a CEDH, visto que permitia a detenção de suspeitos de terrorismo de uma forma discriminatória, com base meramente na nacionalidade, uma vez que os cidadãos britânicos suspeitos da prática do mesmo crime não poderiam ser presos com base nesta norma, mas somente os suspeitos estrangeiros ${ }^{136}$. Nesse sentido, expõe Jenkings:

"No entanto, a detenção da Seção 23 aplicava-se apenas a estrangeiros, enquanto cidadãos igualmente perigosos vagavam livremente. Por essas razões, os Law Lords consideraram que fora violado injustificadamente o direito da Convenção à liberdade, com base somente na origem nacional, proibida pelo Artigo 14." 137

\footnotetext{
${ }^{134}$ Caso A and others v Secretary of State for the Home Department. House of Lords; [2004] UKHL 56; julgado em 16 dez. 2004. Íntegra da decisão disponível em $<$ https://publications.parliament.uk/pa/ld200405/ldjudgmt/jd041216/a\&oth-1.htm>. Acesso em 15 nov. 2018.

${ }^{135}$ JENKINS, David. Citizenship and the Limits of Due Process since 9/11. In: JENKINGS, David; JACOBSEN, Amanda; HENRIKSEN, Anders (Org.). The Long Decade: How 9/11 Changed the Law. Oxford University Press, 2014. p. 180.

${ }^{136}$ Ibid. p. 170.

${ }^{137}$ Ibid. p. 180, tradução livre. No original: "Nevertheless, Section 23 detention applied only to aliens, while similarly dangerous citizens roamed free. For these reasons, the Law Lords found that it
} 
Assim, a maioria da House of Lords emitiu a declaração de incompatibilidade com base tão somente na diferenciação entre suspeitos da prática de terrorismo estrangeiros e cidadãos, criada pelo Anti-terrorism, Crime and Security Act 2001. Apenas Lord Hoffman entendeu que não havia, de fato, uma emergência pública.

Apesar de não implicar na anulação da disposição legal declarada incompatível, nem na libertação dos $\operatorname{presos}^{138}$, a decisão foi intensamente debatida pela mídia e pelos juristas, gerando diversas críticas ao governo. Foi declarado por alguns constitucionalistas que essa teria sido "uma das mais importantes decisões do mais alto tribunal da Grã-Bretanha em 50 anos" ${ }^{\prime 39}$.

Visando amenizar a insatisfação popular com o ocorrido e antecipando uma possível futura condenação pela Corte Europeia de Direitos Humanos, o Parlamento inglês acabou alterando a legislação menos de 1 ano após a decisão supracitada $^{140}$.

A parte 4 do Anti-terrorism Act foi revogada e substituída pelo Prevention of Terrorism Act 2005, que criou o instituto das control orders, no qual se passou a exigir a aprovação do Judiciário quando as restrições aos suspeitos de terrorismo impostas pela Home Secretary fossem incompatíveis com o artigo $5^{\circ}$ da Convenção Europeia de Direitos Humanos, garantidora do direito à liberdade ${ }^{141}$. Além disso, a nova lei retirou a diferenciação feita entre suspeitos

unjustifiably violated the Convention's Article 5 right to liberty on the basis of national origin, prohibited by Article 14."

${ }^{138}$ CYRINO, André Rodrigues. Revolução na Inglaterra? Direitos humanos, corte constitucional e declaração de incompatibilidade das leis. Novel espécie de judicial review? Revista de Direito da Procuradoria Geral. Rio de Janeiro, edição nº 62, 2007. p. 37.

${ }^{139}$ Conforme DYER, Clare; WHITE, Michael; TRAVIS, Alan. Judges' verdict on terror laws provokes constitutional crisis. The Guardian, 17 dez. 2004, tradução livre. No original: "Constitutional lawyers called it one of the most important decisions from Britain's highest court in 50 years". Disponível em $<$ https://www.theguardian.com/uk/2004/dec/17/terrorism.humanrights3>. Acesso em 15 nov. 2018.

${ }^{140}$ CYRINO, André Rodrigues. Op.cit. p. 38.

${ }^{141}$ Conforme Seção 1 do Prevention of Terrorism Act 2005. 
britânicos e estrangeiros, passando a permitir a prisão cautelar também para nacionais.

Apesar de não parecer uma mudança tão significativa no instituto, que continuou sendo bastante controverso ${ }^{142}$, uma vez que continuou permitindo a prisão cautelar de suspeitos de terrorismo por tempo indeterminado, o fato de se estender a possibilidade de imposição da control order aos cidadãos britânicos "resolveu" o cerne da questão da decisão da House of Lords, visto que a maioria da Corte reprovou tão somente a discriminação de cidadãos estrangeiros em detrimento dos cidadãos britânicos feita pela legislação anterior ${ }^{143}$. Ademais, exigir uma autorização do Judiciário em determinadas hipóteses mais restritivas retirou parte da discricionariedade do Executivo, tornando o instituto um pouco mais balanceado.

Nota-se que, posteriormente, até mesmo as control orders acabaram mostrando-se tão controversas que foram revogadas pelo Terrorism Prevention and Investigation Measures Act 2011, que criou o novo instituto vigente até a presente data, as TPIMs (Terrorism Prevention and Investigation Measures), que têm a pretensão de ser um pouco mais brandas do que os dois institutos anteriores $^{144}$.

Dessa forma, sintetiza Jenkings sobre o legado deixado pelo Belmarsh 9 Case:

“Ainda assim, o Caso Belmarsh e o regime de control orders sinalizaram uma mudança
importante no pensamento jurídico britânico; diferentemente de antes, o cidadão não
podia mais esperar direitos especiais à liberdade e ao devido processo legal, que fossem
maiores do que os dos estrangeiros. [...] Com essa decisão, a House of Lords rejeitou
formalmente a antiga abordagem dos direitos discriminatórios da common law em

142 JENKINS, David. Citizenship and the Limits of Due Process since 9/11. In: JENKINGS, David; JACOBSEN, Amanda; HENRIKSEN, Anders (Org.). The Long Decade: How 9/11 Changed the Law. Oxford University Press, 2014. p. 181.

${ }^{143}$ Ibid. p. 1801-181.

${ }^{144}$ Ibid. p. 181. 
favor de uma abordagem universalista sob a Convenção [Europeia de Direitos Humanos]."

\subsection{Efetividade do controle fraco de constitucionalidade: a experiência britânica}

Apesar da alcunha de controle fraco de constitucionalidade, a experiência britânica tem mostrado que as declarações de incompatibilidade emitidas pelo Judiciário têm sido eficientes no sentido de exercer uma pressão sobre o Parlamento para que este altere a norma incompatível com o Human Rights Act e com a Convenção Europeia de Direitos Humanos.

Gardbaum, por exemplo, expõe que há evidências de significativa consideração legislativa e debate em resposta a diversas declarações de incompatibilidade emitidas pelas cortes britânicas ${ }^{146}$.

Nesse mesmo sentido está o relatório elaborado em dezembro de 2017 pelo Lord Chancellor e pelo Secretary of State for Justice britânicos ao Joint Committee on Human Rights ${ }^{147}$ - órgão criado para exerceu uma fiscalização da compatibilidade das novas leis com os direitos humanos ainda na sua fase de elaboração no Parlamento britânico. Nesse relatório são apresentados alguns dados estatísticos sobre as declarações de incompatibilidade emitidas pelas cortes britânicas versus as respostas do Parlamento a essas declarações.

Segundo tal relatório, desde que o Human Rights Act entrou em vigor, em outubro de 2000, até julho de 2017, foram emitidas 37 declarações de

\footnotetext{
${ }^{145}$ Ibid. p. 181-182, tradução livre. No original: "Still, the Belmarsh Case and the control order regime had signaled an important shift in British legal thinking; unlike before, the citizen could no longer expect special rights to liberty and due process that were greater than those for aliens. [...] With that decision, the House of Lords formally rejected the common law's old, discriminatory rights approach in favor of a universalist one under the Convention."

146 GARDBAUM, Stephen. Reassessing The New Commonwealth Model of Constitutionalism. International Journal of Constitutional Law, v. 8, n. 2, 2010. p. 193.

${ }^{147}$ LORD CHANCELLOR AND SECRETARY OF STATE FOR JUSTICE. Responding to Human Rights judgments: Report to the Joint Committee on Human Rights on the Government's response to Human Rights judgments 2016-17. Ministry of Justice, dez. 2017. Disponível em $<$ https://www.gov.uk/government/publications/responding-to-human-rights-judgments-2016-to-2017>. Acesso em 15 nov. 2018.
} 
incompatibilidade, sendo que 25 destas já transitaram em julgado, 3 ainda estão pendentes de apreciação de recurso e 9 foram reformadas em sede de recurso.

Das 25 declarações que se tornaram definitivas, 11 foram remediadas posteriormente por legislação primária ou secundária; 5 eram relacionadas a disposições que já haviam sido corrigidas pelo Parlamento no momento da declaração; 3 foram remediadas através de uma ordem de remediação, prevista na seção 10 da HRA; 5 ainda estão sob consideração sobre como remediar a incompatibilidade; e em uma o Parlamento já foi notificado pelo Governo de que este irá propor uma ordem de remediação ${ }^{148}$.

Assim, através deste relatório podemos observar que todas as declarações de incompatibilidade obtiveram alguma resposta por parte do governo algumas, é claro, foram mais eficientes do que outras, mas fato é que sempre houve uma resposta.

Conforme pondera Cyrino, essa efetividade se deve, em grande parte, ao fato de as declarações de incompatibilidade representarem, na verdade, uma ciência ao Parlamento de que "seu ato é contrário aos direitos humanos, o que gera, no mínimo, algum constrangimento politico interno e externo" ${ }^{" 149}$.

Por exemplo, no caso explorado anteriormente, dos prisioneiros de Belmarsh, apesar da rápida resposta do Parlamento, a nova lei acabou se mostrando quase tão controversa quanto a lei anterior, tendo sido também revogada alguns anos depois. No entanto, o ponto principal levantado pela maioria da House of Lords, qual seja, a discriminação perpetrada pela lei entre suspeitos estrangeiros e cidadãos britânicos foi suprimida na lei posterior, criadora das control orders. Assim, apesar da reprovação popular da nova lei, o

\footnotetext{
${ }^{148}$ LORD CHANCELLOR AND SECRETARY OF STATE FOR JUSTICE. Responding to Human Rights judgments: Report to the Joint Committee on Human Rights on the Government's response to Human Rights judgments 2016-17. Ministry of Justice, dez. 2017. p. 32.

${ }^{149}$ CYRINO, André Rodrigues. Revolução na Inglaterra? Direitos humanos, corte constitucional e declaração de incompatibilidade das leis. Novel espécie de judicial review? Revista de Direito da Procuradoria Geral. Rio de Janeiro, edição nº 62, 2007. p. 36.
} 
que se vê é que esta alterou exatamente o que foi declarado incompatível pela House of Lords.

De tal modo, as declarações de incompatibilidade têm se mostrado mais potentes do que pareceriam ser, pois mandam uma mensagem clara ao governo, ao Parlamento e à sociedade - qual seja, a de que as leis britânicas falharam na adesão ao Human Rights Act 1998 e na consequente observância dos direitos humanos.

Elas têm, portanto, um importante papel de exercer uma pressão política sobre o Gabinete e o Parlamento para alterar a lei declarada incompatível, para que passem a estar de acordo com as normas de direitos humanos positivadas na Convenção Europeia de Direitos Humanos.

E, frise-se, caso isso não ocorra, é também possível levar o caso à Corte Europeia de Direitos Humanos, situada em Estrasburgo. Neste caso, o argumento do recorrente estará bem embasado por uma declaração do Judiciário do próprio Reino Unido, afirmando que aquela norma é incompatível com a $\mathrm{CEDH}$, tornando mais provável a condenação pela $\mathrm{CtEDH}^{150}$. Ao se antecipar essa possível condenação pela CtEDH e acolher as sugestões de uma declaração de incompatibilidade, o Parlamento inglês acaba evitando um futuro desgaste a nível internacional, além de condenações de cunho indenizatório.

Aliás, conforme exposto anteriormente e demonstrando ainda mais o compromisso do Parlamento em fazer cumprir as normas previstas no HRA e na CEDH, foi criado, junto com o início da vigência do Human Rights Act, um Comitê de Direitos Humanos no Parlamento britânico (o Joint Comittee on Human Rights), que tem como papel principal a verificação prévia da compatibilidade dos projetos de lei com o HRA ${ }^{151}$.

\footnotetext{
${ }^{150}$ BERMAN, José Guilherme. Controle fraco de constitucionalidade: sistema jurídico contemporâneo e direito constitucional comparado. Curitiba: Juruá, 2014. p. 177.

151 Nesse sentido, cf. Role of Joint Committee on Human Rights. Disponível em $<$ https://www.parliament.uk/business/committees/committees-a-z/joint-select/human-rightscommittee/role/>. Acesso em 15 nov. 2018.
} 
Fazendo-se um paralelo com o direito brasileiro, como bem pontua Cyrino ao comparar a experiência deste país ao caso dos prisioneiros de Belmarsh, "a conclusão que imediatamente salta aos olhos é a de que a decisão dos Law Lords foi mais eficaz que as decisões em mandados de injunção ou as declaração de inconstitucionalidade por omissão do Supremo Tribunal Federal ${ }^{, 152}$.

Nesse sentido, destaca-se o levantamento disponível no sítio eletrônico do Supremo Tribunal Federal, segundo o qual existem 30 casos em que o STF declarou a mora do Poder Legislativo - seja através de mandado de injunção, seja por meio de ações diretas de controle - e cuja matéria ainda se encontra pendente de disciplina ${ }^{153}$.

Os assuntos relacionados a essas decisões são, por exemplo, (i) a regulamentação da aposentadoria especial prevista no art. $40, \S 4^{\circ}$, da Constituição brasileira, omissão já apontada em 40 (!) oportunidades pelo STF e até hoje não remediada; a regulamentação do direito de greve dos servidores públicos, nos termos do art. 37, VII, da $\mathrm{CRFB}^{154}$; e (ii) a edição de lei complementar federal para criação de municípios, em consonância com o art. $18, \S 4^{\circ}$, da CRFB. Neste último caso, vale observar que, no âmbito da ADI $n^{\circ}$ 3.682/MT, de relatoria do Min. Gilmar Mendes, foi estabelecido, em 09 mai. 2007, um prazo de 18 meses para que o Legislativo adotasse as providências

\footnotetext{
152 CYRINO, André Rodrigues. Revolução na Inglaterra? Direitos humanos, corte constitucional e declaração de incompatibilidade das leis. Novel espécie de judicial review? Revista de Direito da Procuradoria Geral. Rio de Janeiro, edição no 62, 2007. p. 42-43.

153 Supremo Tribunal Federal. Omissão Inconstitucional. Última atualização em 22 mar. 2018. Disponível

$<$ http://www.stf.jus.br/portal/cms/verTexto.asp?servico=jurisprudenciaOmissaoInconstitucional $>$. Acesso em 15 nov. 2018.

${ }^{154}$ Neste caso, tamanha foi a mora do Congresso Nacional em criar a lei que regulamentasse a greve dos servidores públicos - além da enorme relevância do assunto -, que o STF teve que valer-se do seu ativismo judicial para fazer aplicar por analogia a lei de greve dos funcionários de empresas privadas (Lei $\mathrm{n}^{\mathrm{o}} 7.783 / 1989$ ). Nesse sentido, cf. MENDES, Gilmar Ferreira. Curso de direito constitucional. $11^{\mathrm{a}}$ ed.. São Paulo: Saraiva, 2016. p. 1.266-1.275.
} 
cabíveis em relação ao cumprimento da norma constitucional citada acima, não cumprido até hoje, mais de 10 anos após a publicação da decisão ${ }^{155}$.

Acerca da ineficiência do sistema de inconstitucionalidade por omissão brasileiro, pontua Barroso:

\begin{abstract}
"Sem embargo de ter figurado entre as preocupações da doutrina e do constituinte de 1988, o fenômeno da inconstitucionalidade por omissão não é eficientemente resolvido no sistema constitucional brasileiro. Aliás, em todos os países nos quais se pretendeu equacionar o problema - aí incluídos Portugal, Alemanha e Itália -, a questão da inércia constitucional se debate com dificuldades decorrentes do esforço de conciliação entre o princípio da supremacia da Constituição e a separação de Poderes. [...] A literalidade do $\S 2^{\circ}$ do art. 103 e a resistência do STF em dar-lhe sentido mais abrangente, sob o fundamento de que não pode tornar-se legislador positivo, tornaram a ação direta de inconstitucionalidade por omissão um remédio jurídico de baixa eficácia, e consequentemente, de uso limitado." 156
\end{abstract}

Desta forma, nota-se que, mesmo quando comparado com um país que adota uma forma de controle forte de constitucionalidade, como o Brasil, que possui ainda uma crescente tradição de ativismo judicial no que diz respeito à interpretação da Constituição e à invalidação de leis inconstitucionais, o modelo adotado pelo Reino Unido mostra-se bastante eficiente.

Por fim, importante observar que, apesar de todo o exposto, o papel do Human Rights Act pode tomar um novo rumo com a saída do Reino Unido da União Europeia (o "Brexit"), em vias de se concretizar em março de 2019. Apesar de, a princípio, não ocorrer a imediata revogação do Human Rights Act 1998 quando o Brexit se tornar oficial ${ }^{157}$ - uma vez que representa a

${ }^{155}$ Cf. Supremo Tribunal Federal. Omissão Inconstitucional. Última atualização em 22 mar. 2018. Disponível

$<$ http://www.stf.jus.br/portal/cms/verTexto.asp?servico=jurisprudenciaOmissaoInconstitucional $>$. Acesso em 15 nov. 2018.

${ }^{156}$ BARROSO, Luís Roberto. O controle de constitucionalidade no direito brasileiro: exposição sistemática da doutrina e análise crítica da jurisprudência. $4^{a}$ ed. rev. e atual.. São Paulo: Saraiva, 2009. p. 252 e p. $264-265$.

${ }^{157}$ Nesse sentido, cf. JONES, Brian Christopher. Brexit, Rights, and the (Potential) Scrapping of the HRA. Oxford Human Rights Hub, 18 mar. 2016. Disponível em <http://ohrh.law.ox.ac.uk/brexit-rightsand-the-potential-scrapping-of-the-hra/>; AMED, Khadija. Reflecting On The Human Rights Act 1998 And 'Bringing Rights Home'. Rights Info, 9 nov. 2018. Disponível em $<$ https://rightsinfo.org/on-thehuman-rights-act-1998-and-bringing-rights-home/>; e ISAAC, David. As We Look To Brexit It's Vital We Reinforce Our Human Rights Protections. Rights Info, 9 nov. 2018. Disponível em 
internalização da Convenção Europeia de Direitos Humanos, fazendo parte do direito britânico, e não do direito comunitário europeu -, há uma crescente tendência conservadora no Reino Unido contrária às limitações criadas pelo HRA e pela $\mathrm{CEDH}^{158}$. É de se notar, inclusive, que a atual Primeira-Ministra do Reino Unido, Theresa May, na época em que era Home Secretary, prometeu que acabaria com o Human Rights Act ${ }^{159}$. Assim, com a sua ascensão para o cargo de Primeira-Ministra logo após o referendo do Brexit, essa promessa poderá ser mais facilmente cumprida. No entanto, essas são meras projeções para o futuro, não havendo como se dizer, ao certo, qual será o destino o Human Rights Act.

$<$ https://rightsinfo.org/as-we-look-to-brexit-its-vital-we-reinforce-our-human-rights-protections/>. Acesso em 15 nov. 2018.

${ }^{158}$ Nesse sentido: JUNIOR, Otavio Luiz Rodrigues. Partido britânico quer fim de Lei dos Direitos Humanos. Conjur, 23 out. 2013. Disponível em <https://www.conjur.com.br/2013-out-23/direitocomparado-partido-britancio-fim-lei-direitos-humanso>. Acesso em 15 nov. 2018.

${ }^{159}$ HANNAN, Martin. Will a post-Brexit UK remain in the European Court of Human Rights? The National, $1^{\circ}$ nov. 2018. Disponível em <https://www.thenational.scot/news/17192518.will-a-postbrexit-uk-remain-in-the-european-court-of-human-rights/>. Acesso em 15 nov. 2018. 


\section{Conclusão}

Apesar de não poder se dizer, necessariamente, que os instrumentos trazidos pelo Human Rights Act caracterizariam um modelo de controle de constitucionalidade propriamente dito - ou um controle de constitucionalidade "forte" -, não há como se negar que a criação da obrigação interpretativa e, sobretudo, a da declaração de incompatibilidade representaram uma significativa mudança no Direito Constitucional britânico, possibilitando alguma forma de fiscalização da atividade legislativa pelo Judiciário ${ }^{160}$, prerrogativa inédita na História constitucional inglesa.

Não obstante o fato de que o Judiciário não possa invalidar a norma e nem sequer deixar de aplicá-la no caso concreto, o que se vê na prática é que uma declaração emitida pelo Judiciário de que alguma norma britânica é incompatível com determinados direitos humanos é tão constrangedora para o Legislativo britânico que este acaba sempre remediando a incompatibilidade de alguma forma.

O relativo sucesso da experiência britânica com o controle fraco é bem distante, por exemplo, da experiência brasileira com o instituto da inconstitucionalidade por omissão, prevista no art. 103, § 2 ${ }^{\circ}$, da CRFB. Apesar das inúmeras decisões do Supremo Tribunal Federal declarando moras do legislativo em criar leis requeridas pela Constituição - muitas delas de mais de uma década atrás -, alguns dispositivos constitucionais deixam de ser aplicados há 30 anos por ausência de regulamentação.

Por todo o exposto, conclui-se que, apesar do modelo de controle jurisdicional de constitucionalidade adotado pelo Reino Unido não permitir que o Judiciário obrigue o Parlamento a alterar determinada legislação incompatível

\footnotetext{
${ }^{160}$ CYRINO, André Rodrigues. Revolução na Inglaterra? Direitos humanos, corte constitucional e declaração de incompatibilidade das leis. Novel espécie de judicial review? Revista de Direito da Procuradoria Geral. Rio de Janeiro, edição nº 62, 2007. p. 38.
} 
com Human Rights Act e nem invalide ou deixe de aplicar a norma declarada incompatível, as cortes britânicas têm sido, em geral, bem-sucedidas em constranger o Parlamento britânico a remediar a incompatibilidade, seja por exercerem uma pressão política e gerarem certo constrangimento sobre o governo para alterar a legislação, seja por anteciparem uma possível condenação pela Corte Europeia de Direitos Humanos, que seria politicamente muito mais desvantajosa para o Reino Unido.

Deve-se observar, contudo, que esta conjuntura foi analisada em um contexto que precede à formalização do Brexit, não havendo como prever, com absoluta certeza, qual será o futuro do Human Rights Act após a saída do Reino Unido da União Europeia. 


\section{Bibliografia}

AMED, Khadija. Reflecting On The Human Rights Act 1998 And 'Bringing

Rights Home'. Rights Info, 9 nov. 2018. Disponível em $<$ https://rightsinfo.org/on-the-human-rights-act-1998-and-bringing-rightshome/>. Acesso em 15 nov. 2018.

BAGEHOT, Walter. Its History, and the Effects of That History - Conclusion. In: BAGEHOT, Walter. The English Constitution. $2^{\mathrm{a}}$ ed.. 1873. p. 201-213. Disponível em $<$ https://socialsciences.mcmaster.ca/econ/ugcm/3113/bagehot/constitution.pdf $>$. Acesso em 15 nov. 2018.

BARROSO, Luís Roberto. O controle de constitucionalidade no direito brasileiro: exposição sistemática da doutrina e análise crítica da jurisprudência. $4^{\mathrm{a}}$ ed. rev. e atual.. São Paulo: Saraiva, 2009. 388 p.

BARROSO, Luís Roberto. Curso de direito constitucional contemporâneo: os conceitos fundamentais e a construção do novo modelo. $2^{\text {a }}$ ed.. São Paulo: Saraiva, 2010. $453 \mathrm{p}$.

BELlAMY, Richard. Political constitutionalism and the Human Rights Act. International Journal of Constitutional Law, v. 9, jan. 2011. p. 86-111. Disponível em <https://doi.org/10.1093/icon/mor024>. Acesso em 15 nov. 2018.

BERMAN, José Guilherme. Controle fraco de constitucionalidade: sistema jurídico contemporâneo e direito constitucional comparado. Curitiba: Juruá, 2014. $257 \mathrm{p}$. 
BINENBOJM, Gustavo. A nova jurisdição constitucional: Legitimidade democrática e instrumentos de realização. $4^{\mathrm{a}}$ ed. revista, ampliada e atualizada. Rio de Janeiro: Renovar, 2014. 319 p.

CAPPELLETTI, Mauro. O controle judicial de constitucionalidade das leis no direito comparado. Tradução de Aroldo Plínio Gonçalves. $2^{\text {a }}$ ed., reimpressão. Porto Alegre: Fabris, 1984. 142 p.

CYRINO, André Rodrigues. Revolução na Inglaterra? Direitos humanos, corte constitucional e declaração de incompatibilidade das leis. Novel espécie de judicial review? Revista de Direito da Procuradoria Geral. Rio de Janeiro, edição $\mathrm{n}^{\mathrm{o}} 62,2007$. p. $27-44$.

DICEY, Albert Venn. Introduction to the study of the law of the constitution. $8^{\mathrm{a}}$ ed., reimpressão. Londres: Macmillian, 1915. 584 p. Disponível em $<$ http://files.libertyfund.org/files/1714/0125_Bk.pdf>. Acesso em 15 nov. 2018.

DYER, Clare; WHITE, Michael; TRAVIS, Alan. Judges' verdict on terror laws provokes constitutional crisis. The Guardian, 17 dez. 2004. Disponível em $<$ https://www.theguardian.com/uk/2004/dec/17/terrorism.humanrights3 $>$.

Acesso em 15 nov. 2018.

FITZGERALD, Peter L., Constitutional crisis over the proposed Supreme Court for the United Kingdom. Temple International \& Comparative Law Journal, v. 18, 2004. p. 233-268. Disponível em <https://ssrn.com/abstract=643801>. Acesso em 15 nov. 2018. 
GARDBAUM, Stephen. The New Commonwealth Model of Constitutionalism. American Journal of Comparative Law, v. 49, 2001. p. 707-760.

GARDBAUM, Stephen. Reassessing The New Commonwealth Model of Constitutionalism. International Journal of Constitutional Law, v. 8, n. 2, 2010. p. 167-206.

HANNAN, Martin. Will a post-Brexit UK remain in the European Court of Human Rights? The National, $1^{\circ}$ nov. 2018. Disponível em $<$ https://www.thenational.scot/news/17192518.will-a-post-brexit-uk-remain-inthe-european-court-of-human-rights/>. Acesso em 15 nov. 2018.

ISAAC, David. As We Look To Brexit It's Vital We Reinforce Our Human Rights Protections. Rights Info, 9 nov. 2018. Disponível em $<$ https://rightsinfo.org/as-we-look-to-brexit-its-vital-we-reinforce-our-humanrights-protections/>. Acesso em 15 nov. 2018.

JENKINS, David. Citizenship and the Limits of Due Process since 9/11. In: JENKINGS, David; JACOBSEN, Amanda; HENRIKSEN, Anders (Org.). The Long Decade: How 9/11 Changed the Law. Oxford University Press, 2014. p. 169-184. Disponível em <https://ssrn.com/abstract=2319443>. Acesso em 15 nov. 2018.

JONES, Brian Christopher. Brexit, Rights, and the (Potential) Scrapping of the HRA. Oxford Human Rights Hub, 18 mar. 2016. Disponível em $<$ http://ohrh.law.ox.ac.uk/brexit-rights-and-the-potential-scrapping-of-thehra/>. Acesso em 15 nov. 2018. 
JUNIOR, Otavio Luiz Rodrigues. Partido britânico quer fim de Lei dos Direitos Humanos. Conjur, 23 out. 2013. Disponível em $<$ https://www.conjur.com.br/2013-out-23/direito-comparado-partido-britanciofim-lei-direitos-humanso>. Acesso em 15 nov. 2018.

LORD CHANCELLOR AND SECRETARY OF STATE FOR JUSTICE. Responding to Human Rights judgments: Report to the Joint Committee on Human Rights on the Government's response to Human Rights judgments 2016-17. Ministry of Justice, dez. 2017. Disponível em $<$ https://www.gov.uk/government/publications/responding-to-human-rightsjudgments-2016-to-2017>. Acesso em 15 nov. 2018.

MENDES, Gilmar Ferreira. Curso de direito constitucional. 11 ${ }^{\text {a }}$ ed.. São Paulo: Saraiva, 2016. 1.504 p.

PEMBERTON, Becky. What is a general election, how is the Prime Minister elected and who's allowed to vote in the UK? The Sun, 11 jan. 2018. Disponível em <https://www.thesun.co.uk/uncategorized/3354279/general-election-ukprime-minister-vote/>. Acesso em 15 nov. 2018.

SMIT, Jan van Zyl. The New Purposive Interpretation of Statutes: HRA Section 3 after Ghaidan v Godin-Mendoza. The Modern Law Review, v. 70, fev. 2007. p. 294-306. Disponível em <https://doi.org/10.1111/j.14682230.2007.00638.x>. Acesso em 15 nov. 2018.

TUSHNET, Mark V. New Forms of Judicial Review and the Persistence of Rights - And Democracy-Based Worries. Georgetown Law Faculty Publications and Other Works, 2003. p. 813-838. Disponível em 
$<$ https://scholarship.law.georgetown.edu/facpub/247>. Acesso em 15 nov. 2018.

UDICE, Kristina. 10 ways the world changed after the 9/11 attacks. Insider, 10 set. 2018. Disponível em <https://www.thisisinsider.com/world-changed-afterseptember-11-2018-9>. Acesso em 15 nov. 2018.

WINTERMAN, Denise. Belmarsh - Britain's Guantanamo Bay? BBC News, 6 out. $2004 . \quad$ Disponível em $<$ http://news.bbc.co.uk/2/hi/uk_news/magazine/3714864.stm>. Acesso em 15 nov. 2018.

WOODHOUSE, Diana. The Constitutional Reform Act 2005: defending judicial independence the English way. International Journal of Constitutional Law, v. 5, jan. 2007. p. 153-165, Disponível em <https://doi.org/10.1093/icon/mo1039>. Acesso em 15 nov. 2018. 
Pontifícia U Uiversidade Católica $_{\text {a }}$

DO RIO DE JANEIRO

NORMAS PARA ELABORAÇÃO E APRESENTAÇÃO DA MONOGRAFIA

\section{ANEXO II}

A Monografia deve ser entregue até o dia 21 de novembro de 2018

A presente Monografia, apresentada pelo (a) aluno (a) llara Homson endrade

poderá ser submetida à exposição e defesa perante a Banca Examinadora designada pelo Departamento de Direito da PUC-Rio.

Rio de Janeiro, 19 de movembro de 2018.

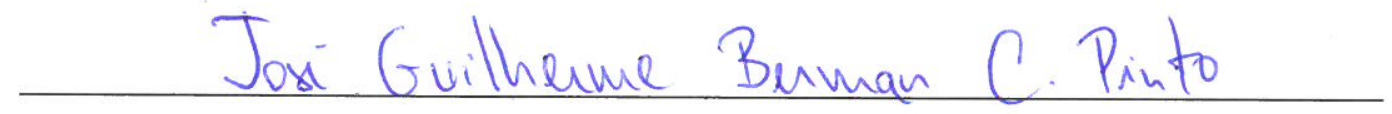

Nome do (a) professor (a) orientador (a)

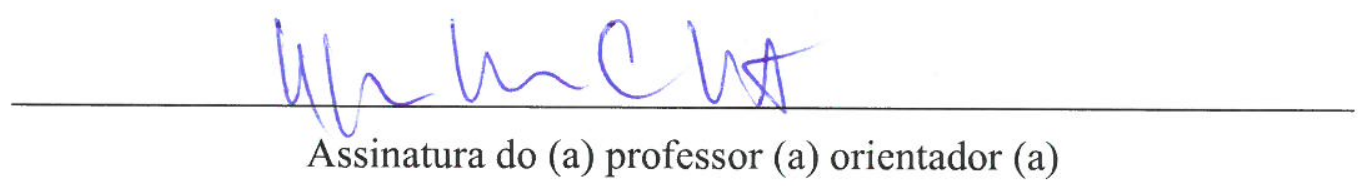

O (A) autor (a) deste trabalho declara para todos os fins de Direito ser este um trabalho inédito e autoriza o Departamento de Direito da PUC-Rio a divulgá-lo, no todo ou em parte, resguardados os direitos autorais conforme legislação vigente.

Rio de Janeiro, 21 de novembro 2018.

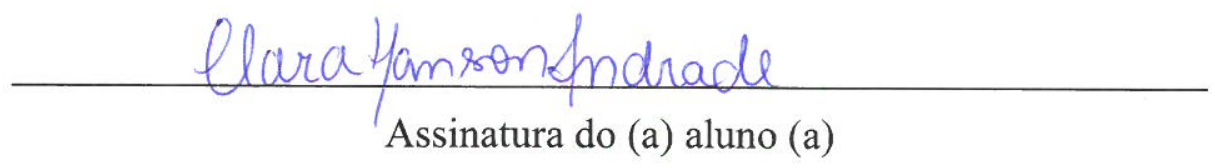

